Ks. Mariusz SZRAM

(Lublin, KUL)

\title{
AUTOKASTRACJA ORYGENESA - FAKT CZY NIEPOROZUMIENIE?
}

Mial rację wybitny współczesny teolog szwajcarski Hans Urs von Balthasar, gdy pisał: „Nie ma w Kościele innego myśliciela, który tak niewidzialnie wszędzie pozostał jak Orygenes" . Aleksandryjczyk z geniuszem przerastającym zdecydowanie swoje czasy usiłował jako pierwszy tworzyć model egzegezy Pisma świętego, łączący naukową precyzję z ukierunkowaniem duchowym. Próbował także tworzyć i precyzować pojęcia teologiczne oraz budować pierwszą w dziejach chrześcijaństwa, jeszcze mocno hipotetyczną i poszukującą, ale zawierającą genialne intuicje, summę teologiczną. Nie ma przesady w powtarzanej w starożytności chrześcijańskiej opinii, zabarwionej skądinąd panegiryczno-retorycznym patosem, zachowanej w pismach Hieronima i Rufina z Akwilei. Opinia ta brzmi: „Orygenes był drugim po Apostołach Kościoła nauczycielem wiedzy i mądrości (alter post apostolos Ecclesiae doctor scientiae ac sapien-

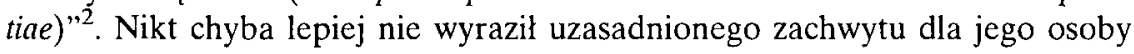
i myśli, niż wspomniany Urs von Balthasar: „Nie da się w żaden sposób przecenić Orygenesa i jego znaczenia dla historii chrześcijańskiej myśli. Dopiero postawić go obok Augustyna i Tomasza oznacza przyznać mu miejsce należne w tej historii. Każdemu, kto zajmował się dłużej badaniem Ojców objawia się on jakby temu, kto wspina się po górach; powoli, ale stale toną szczyty wokół niego, te które zdawały mu się zagrażać, a spoza nich wznosi się w górę dotąd ukryty, ale zajmujący środek królewski masyw. Nikt wśród wielkich, od Kapadocczyków do Augustyna, do Dionizego, Maksyma, Szkota Eriugeny i Eckharta nie mógł się uwolnić od tej prawie magicznej siły promieniowania tego „człowieka ze stali" [Adamantios], bo tak go nazywano. Niektórzy [Euzebiusz z Cezarei, Grzegorz z Nyssy, Ambroży czy Hieronim] zatracili się w nim całkowicie"3.

${ }^{1}$ H. Urs von Balthasar, Wstęp, w: Orygenes, Duch i Ogień, wybór tekstów i oprac. H. Urs von Balthasar, tłum. S. Kalinkowski, Kraków - Warszawa 1995, 8.

${ }^{2}$ Origenes, De principiis Praefatio Rufini 1, SCh 252, 68-70; PSP 23, 57-58: Hieronymus, Praefatio ad Homilias Origenis in Ezechielem, SCh 352, 30.

${ }^{3}$ Von Balthasar, dz. cyt., s. 7. Wiele tekstów Ambrożego można nazwać wręcz „plagiatami" komentarzy biblijnych i homilii Orygenesa. 
Niestety, losy pośmiertne Orygenesa potoczyły się tragicznic. Spory wokół jego doktryny wyjętej z kontekstu historyczno-teologicznego, w jakim powstała, a także znickształconej przez mniej zdolnych teologów i mnichów, spowodowały, że do jego imienia przylgnçło na lata miano blędnowiercy (głównie zwolennika teorii preegzystencji dusz i apokatastazy) i ojca późniejszych herezji (zwłaszcza arianizmu). Dopiero w XX wieku, dzięki badaniom patrologów niemieckich (W. Völker, A. Lieske, H. Koch), a później francuskich (J. Daniélou, H. de Lubac, H. Crouzel), przywrócono Orygenesowi sprawiedliwość, dostrzegając w nim nie tylko wybitnego filozofa, ale przede wszystkim egzegetę, interpretatora doktryny chrześcijańskicj i teologa duchowości. Wciąż jednak najkrótsza charakterystyka jcgo osoby ogranicza się często nie do podkreślania zasług intelektualnych, ale do sformułowania - „ten, który w młodości dopuścił się samokastracji". Budzi to niejednokrotnie podejrzenie wobec Orygenesa i odstrasza od poważnego traktowania jego dorobku. Tymczasem sprawa jest o wicle bardziej złożona niż wydaje się na pierwszy rzut oka. Źródła nie są jednoznaczne i wywołują trwającą stale dyskusję wśród historyków starożytnego chrześcijaństwa i patrologów, usiłujących dociec nie tylko dlaczego i w jaki sposób Orygenes dopuścił się autokastracji, ale również podających w wątpliwość autentyczność tego czynu.

Niniejszy artykul stanowi podjętą na podstawie zachowanych źródeł, skonfrontowanych ze współczesnymi interpretacjami badaczy, próbę przynajmniej częściowej odpowiedzi na następujące pytania:

- Co przemawia za tym, że autokastracja Orygenesa faktycznie miała miejsce, a co za tym, że było to posądzenie ?

- Jeżeli istotnie do niej doszło, to z jakich motywów?

- Jaka mogła być reakcja na taki czyn wśród współczesnych Orygenesowi i czy byl on odosobniony?

- Jaki był stosunek ówczesnego prawa kościelnego i teologii do dosłownej interpretacji tekstów biblijnych, prowadzącej do takich aktów?

- Jeżeli natomiast nie ma pewności, że takie zdarzenie miało miejsce, to co spowodowało, że Aleksandryjczykowi przypisano ten czyn?

Najpierw przedstawię argumenty przemawiające za autentycznością czynu Orygenesa, ukazując przy okazji niezbędne to historyczne związane z problemem kastracji we wczesnym Kościele, sięgając również do starożytnych źródeł niechrześcijańskich ${ }^{4}$. Następnie dokonam prezentacji argumentów przemawia-

${ }^{4}$ W ostatnim czasie ukazały się w środowisku amerykańskim co najmniej dwa przekrojowe opracowania, dotyczące wczesnochrześcijańskiego eunuchizmu: G.R. Brower, Ambivalent bodies. Making Christian etmuchs, Diss. Duke Univ. 1996; M. Kuefler, The Manly Eunuch: Masculinity, Gender Ambiguity and Christian Ideology in Late Antiquity, Chicago 2001 (przede wszystkim rozdzial 8: "Etunuchs for the Sake of the Kingdom of Heaven" - Castration and Christian Manliness). Do pierwszego z nich nie udało mi się, niestety, dotrzeć. Zasadnicze tezy ostatniego, związane tylko częściowo z poruszanym tu zagadnieniem, poznałem z autorskiego streszczenia książki, 
jących przeciw autokastracji Aleksandryjczyka. Zestawienie argumentów za i przeciw umożliwi sformułowanic podsumowujących wniosków, pozwalających jeśli nie na ostateczną odpowiedź na pytanie postawione w tytule referatu, to przynajmniej na wyrobienie sobie własnego stanowiska $w$ tej kwestii. Taką metodą wykładu posługiwał się zresztą sam Orygenes. Prezentował możliwie jak największą ilość różnych opinii dotyczących omawianego zagadnienia, także dyskusyjnych czy wręcz błędnych, po czym zajmował własne stanowisko bądź unikal zdecydowanego rozstrzygnięcia, pozostawiając decyzję odbiorcy, albo tcż wyrażał pokorną nadzieję, że w przyszłości pojawi się ktoś zdolniejszy, kto przedstawi lepiej daną kwestię. Pójdźmy i my jego tropem ...

\section{ARGUMENTACJA ZA UZNANIEM AUTOKASTRACJI ORYGENESA ZA FAKT}

O czynie Orygenesa i jego motywach dowiadujemy się z Historii Kościelnej Euzebiusza z Cezarei:

"Gdy Orygenes w Aleksandrii sprawowal obowiązki katechety, dokonal czynu, świadczącego niewątpliwie o niedojrzałości i młodości jego usposobienia, ale także o jego wierze i powściągliwości. Otóż słowa: «Są tacy bezżenni (zủvoúxol), którzy sami ze względu na Królestwo niebieskie uczynili się niezdolnymi do małżeństwa» (Mt 19,12), rozumiał zbyt prosto i dziecinnie, i chcial $z$ jednej strony wypełnić to, co Pan powiedział, $z$ drugiej zaś strony pragnąl niewiernym odebrać wszelki powód do brzydkiego posądzania, jako że w tak młodym wieku głosił słowo Boże nie tylko mężczyznom, ale także niewiastom. Postanowił więc wykonać rzeczywiście słowa Zbawiciela [..."

P. Brown uważa, że zdarzenic to mogło mieć miejsce najpóźnicj ok. 206 r., a więc gdy Orygenes skończył 20 lat $^{6}$. Świadectwo Euzebiusza pochodzi dopicro z 1. pol. IV wieku (306-325), czyli powstało ponad pół wicku po śmierci Orygenesa. Jest pierwszym zachowanym i wlaściwie jedynym w starożytnej

zamieszczonego $w$ internecie. Zagadnienie eunuchizmu w Bizancjum stało się przedmiotem opublikowanych w ostatnich latach studiów: Third sex, third gender, red. G. Herdt, New York 1994; Women, men and eunuchs. Gender in Byzantium, red. L. James, London 1997.

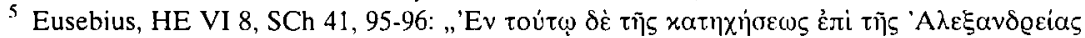

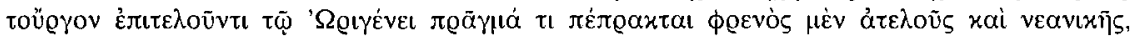

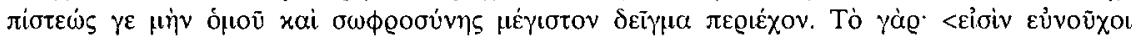

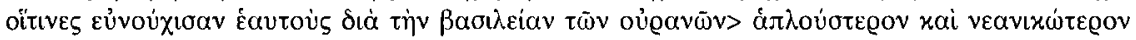

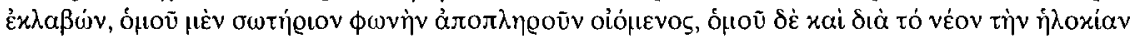

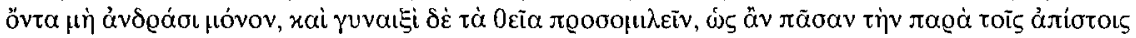

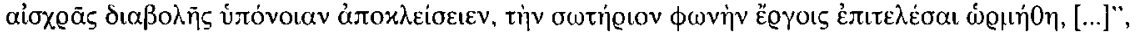
tłum. A. Lisiecki, POK 3, 259-260.

${ }^{6}$ Por. P. Brown, The Body and Society. Men, Women and Sexual Renunciation in Early Christianity, New York 1988, 168. 
literaturze chrześcijańskiej wyraźnym i zdecydowanym potwierdzeniem czynu Aleksandryjczyka. Na tym przekazie opierają się Hieronim i późniejsi biografowie. Natomiast Epifaniusz, który, jak zobaczymy niżej, będzie miał wątpliwości co do samokastracji Orygenesa, powołuje się na bliżej nieokreśloną ustną tradycję. Badacze opowiadający się za wiarygodnością przekazu Euzebiusza (H. Crouzel, P. Nautin, R.P.C. Hanson, P. Brown, W.J. Trigg) uważają, że korzystał on w tym wypadku ze sprawdzonych źródeł, miał bowiem dostęp do korespondencji Aleksandryjczyka i do jego biblioteki założonej w Cezarei, a także do zbioru prywatnych listów biskupa Jerozolimy - Aleksandra, udzielającego święceń Orygenesowi ${ }^{7}$. Ponadto twierdzą, że Euzebiusz, jako zwolennik Orygenesa, pominąłby informację mogącą stawiać w nienajlepszym świetle swojego ulubionego bohatera, gdyby była ona niepewna.

W dalszej części swej relacji Euzebiusz opisuje dość zaskakującą, dwuetapową reakcję na czyn Orygenesa ze strony jego biskupa - Demetriosa:

„[...] dowiedział się o tym później Demetrios, zwierzchnik tamtejszego Kościoła, i zdumiał się niezmiernic nad śmiałością czynu Orygenesa, pochwalił jego gorliwość i szczerość wiary, pokrzepił go na duchu i wezwał, by teraz tym gorliwiej spełniał obowiązki katechety. [...] niedługo potem, gdy patrzył na powodzenie Orygenesa i na szerzący się powszechnie rozglos jego wielkości i sławy, ludzką powodowany ułomnością, usiłował w listach, rozpisanych do biskupów calego świata, czyn Orygenesa przedstawić jako rzecz zgoła przewrotną. Tak zrobil dlatego, poniewaz najznakomitsi i najznaczniejsi biskupi palestyńscy, cezarejski i jerozolimski, uznali, że Orygenes zasłużył na odznaczenie oraz najwyższe zaszczyty, i przez włożenie rąk udzielili mu kaplaństwa. A więc gdy Orygenes uzyskal rozglos tak wielki, gdy imię jego bylo wszędy na ustach wszystkich, gdy sobie zdobył sławę cnoty i mądrości, tedy właśnie Demetrios, [...] wytoczył przeciwko niemu złośliwe a ciężkie oskarżenie o czyn, już dawno, w latach wczesnej mlodości spełniony [...]",

Jeżeli uznać przekaz Euzebiusza za autentyczny, to pierwsza $z$ opisanych przez niego reakcji Demetriosa, z racji swego pozytywnego charakteru pozwala do-

${ }^{7}$ Por. Eusebius, HE VI 20, 1, SCh 41, 119-120; M. Szram, Orygenes o kaptanistwie. Antologia tekstów, Olsztyn 1988, 15.

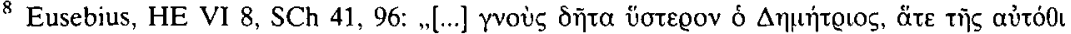

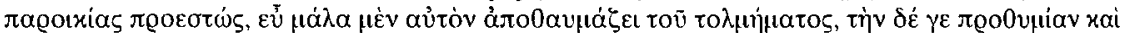

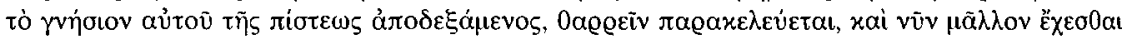

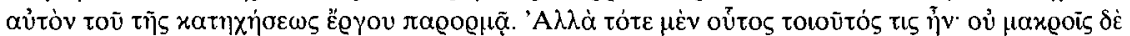

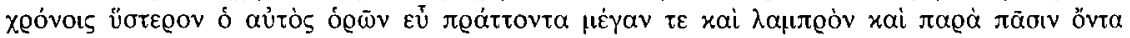

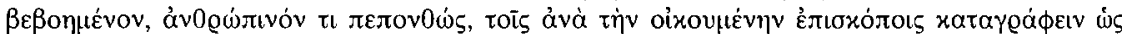

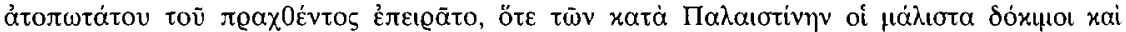

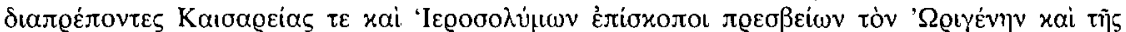

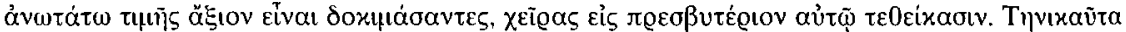

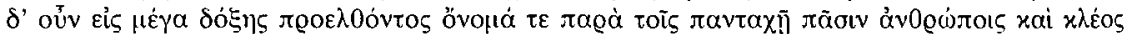

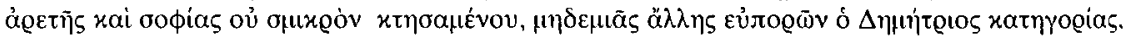

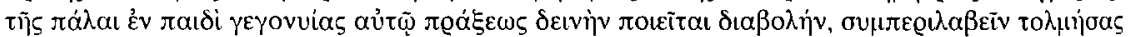

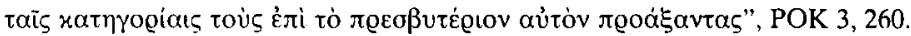


mniemywać, że praktyka samokastracji z pobudek ascetycznych była w tym czasie w Kościele (przynajmniej w Kościołach lokalnych, zwłaszcza na Wschodzie) zjawiskiem spotykanym, przynajmniej wśród osób świeckich, i choć zaskakującym i niedojrzałym, nie wywołującym jednak wielkich zastrzeżeń, wręcz przeciwnie, zasługującym nawet na podziw. Nie da się jednak wykluczyć w tym miejscu apologetycznej manipulacji Euzebiusza, który zdaniem G. Bardy’ego, wydawcy jego Historii Kościelnej, mógł wymyślić taką reakcję Demetriosa, aby osłabić negatywny wydźwięk czynu Orygenesa ${ }^{9}$. Druga, negatywna reakcja biskupa Aleksandrii została przez Euzebiusza umotywowana jedynic zazdrością, a nie jakimś prawem zabraniającym święcenia kastratów. Wprawdzie zredagowane ok. 381 r. Kanony Apostolskie, zabraniające udzielania święceń dobrowolnym kastratom, nawiązują do wcześniejszcj tradycji ustnej, ale dokładny czas jej powstania i terytorialny zasięg obowiązywania są trudne do ustalenia ${ }^{10}$. Jeśli więc biskupi Aleksander i Teoktyst udzielili Orygenesowi święceń, to albo nie znali takiej tradycji albo nie zdawali sobie sprawy z tego, że jest on autokastratem.

Czy sytuacja opisana przez Euzebiusza była możliwa i czy była czynem odosobnionym? Aby odpowiedzieć na to pytanie trzeba odwołać się do innych źródeł wczesnochrześcijańskich i do ogólnego tła historycznego związanego $z$ dziejami kastracji w świecie starożytnym ${ }^{11}$.

$\mathrm{Z}$ pierwszych trzech stuleci istnienia Kościoła zachowały się, oprócz Euzebiuszowej wzmianki o autokastracji Orygenesa, inne świadectwa występowania wśród pierwszych chrześcijan dziwnych, z dzisiejszego punktu widzenia, przejawów ascetycznej gorliwości, wynikającej z przekonania, że odcięcie źródła pokusy i grzechu, za jakie uważano męskie genitalia, prowadzi do czystości i świętości. Źródła te wskazują również na dodatkowe motywy popełnienia

${ }^{9}$ Por. G. Bardy, SCh 41 , s. 96, przyp. 3.

${ }^{10}$ Kościół Wschodni na synodzie II „in Trullo” w 692 r. przyjąl wszystkie 85 kanonów jako prawo obowiązujące. Na Zachodzie jednak papież Gelazy (492-496) uznał je za apokryf. Przypisywano je arianinowi Julianowi, który miał je zredagować w latach 381-394.

11 Proweniencja eunuchizmu jest zdecydowanie wschodnia. Według Herodota był to wynalazek asyryjski. Również u tego ojca historiografii greckiej znajdujemy informację (Historiae VI 32), że Persowie stosowali kastrację jako karę na jeńcach, np. w Jonii, por. W. Szumowski, O eunuchach $i$ kastracji $w$ różnych krajach i czasach, Kraków 1946, 5. Bardzo stara jest na Wschodzie kara kastracji za cudzołóstwo i inne wykroczenia seksualne, o czym świadczą środkowoasyryjskie tabliczki z tekstami przepisów prawnych z II tysiąclecia przed Chrystusem, zob. R. Muth, Kastration, RACh XX 299. W greckich miastach-państwach właśnie pod wpływem Persów, pojawiło się już w IV wieku przed Chr. zjawisko dworskiego eunuchizmu. Euagoras, król Salaminy cypryjskiej (411/410 - 374/373) zginął zamordowany, wpadłszy w zasadzkę przygotowaną przez eunucha Trazydajosa z Elidy, który zarówno jemu, jak i jego synowi ułatwił początkowo stosunki miłosne z córką niejakiego Nikokreonta, por. Aristoteles, Politeia 5, 10 (1311 b 4-6). U starożytnych Greków, Rzymian i Żydów znana była praktyka kastracji jako środka terapeutycznego w niektórych chorobach, np. w trądzie czy epilepsji, zob. Muth, dz. cyt., k. 297. 
takiego czynu. W poł. II w. św. Justyn ${ }^{12}$ wspomina o pewnym młodym chrześcijaninie z Aleksandrii, którego historia wykazuje podobieństwo do przekazu Euzebiusza o Orygenesic. Młodzieniec ów, chcąc przeciwdziałać oskarżeniom ze strony pogan pod adresem ,sckty” chrześcijan o rzekome praktyki nieczyste podczas nocnych spotkań, zwrócił się do Feliksa - prefekta Egiptu (150-152/3), żeby wyznaczył mu lekarza do wykonania operacji. Feliks odmówił, a młody człowiek zadowolił się trwaniem $w$ dobrowolnie zachowanym dziewictwie. Zastanawiająca jest dość obojętna reakcja Justyna na to zdarzenie. Nie pochwala on postępowania młodzieńca, ale też go nie krytykuje. Widoczna w przypadku owego młodzieńca apologetyczna chęć podkreślenia wobec pogan własnej czystości zewnętrznym znakiem kastracji mogła być jednym z głównych jej motywów u chrześcijan, co zdaje się potwierdzać argumentacja Euzebiusza, przytoczona w relacji o autokastracji Orygenesa: ,pragnął niewiernym odebrać wszelki powód do brzydkiego posądzania, jako że w tak młodym wieku głosił słowo Boże nie tylko mężczyznom, ale także niewiastom"13.

Takim czynom jak kastracja mogły sprzyjać wśród pierwszych chrześcijan również wszelkie doktryny dualistyczne, wrogie wobec materii i tego, co cielesne, jak np. przytoczone przez Tertuliana przekonanic Marcjona: „[Jego Bóg] nie łączy małżeństw, zawartych nie uznaje, tylko bezżennego albo eunucha"14. W apokryficznych Aktach Jana, również z poł. II wieku, autorstwa niejakiego Leuciusa Charinusa, właśnie o nastawieniu gnostyckim, zawarty jest przekaz o młodym człowieku, który wykastrowal się krótko po nawróceniu. Apostol Jan upomniał go, że powinien raczej „obrzezać” swoje emocje, a nie członki ${ }^{15}$. Epifaniusz z Salaminy wspomina o szalonych czlonkach arabsko-chrześcijańskiej

12 Por. Apologia I 29, 2-3, PG 6, 373.

13 Eusebius, HE VI 8. SCh 41, 95-96. POK 3, 259-260. O tego rodzaju niebezpiecznych podejrzeniach, których chrześcijanie woleli uniknąć, możemy przeczytać również w Oktawiuszu Minucjusza Feliksa (ok. 170-175), gdzie poganin Cecyliusz stwierdza, że wyznawcy nowej religii poznają się między sobą po tajemnych znakach i panuje miedzy nimi kult rozkoszy zmysłowej: nazywają się be\% róźnicy braćmi i siostrami, aby zwykly nierząd uczynić kazirodztwem, zob. Minucius Felix, Octavius 9, 2, CSEL 2, 13.

14 Tertullianus, Adversus Marcionem IV 11, 8, CCL 1. 567: „[...] coniunctas non admittit, neminem tinguit nisi caelibem aut spadonem”. Trudno pogodzić tę relację o sprzyjaniu Marcjona dobrowolnej kastracji dla zachowania czystości z innym jego poglądem, przytoczonym przez Orygenesa, jakoby Marcjon usuwal z Pisma św. fragment Mt 19, 12, ponieważ był on dla niego w znaczeniu dosłownym nie do przyjęcia, a interpretacji alegorycznej Marcjon nie dopuszczał, zob. Origenes, Commentaritis in Mathaeum XV 3, PG 13, $1261 \mathrm{AB}$.

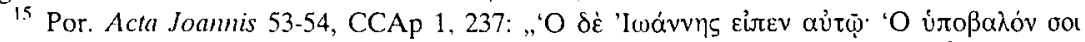

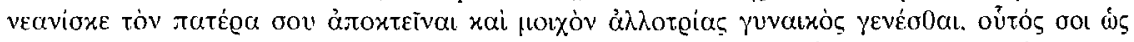

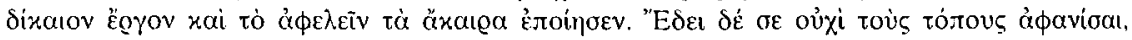

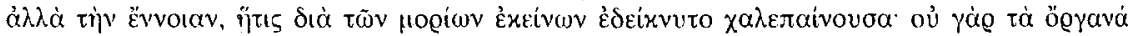

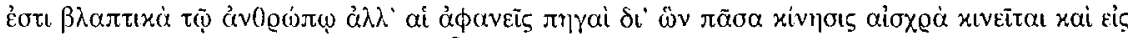

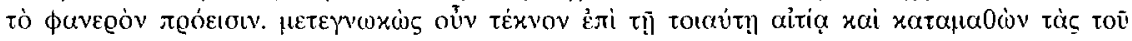

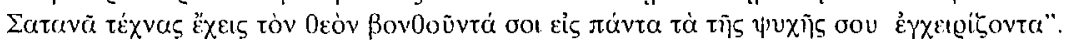


sekty Walezjan z Zajordania, pod względem doktrynalnym zbliżonej do gnos-

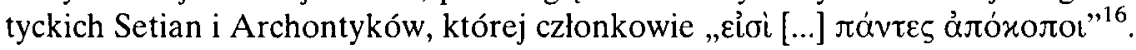
Wierzyli oni, że kastracja chroni człowieka przed wszelkimi złymi skłonnościami. Kiedy przyjmowali kogoś do swojej sekty, nie pozwalali mu spożywać mięsa, dopóki nie dal się wykastrować. Potem, jako już zabezpieczony przed wszelkimi pokusami ciała, mógł jeść i pić, czegokolwiek sobie zażyczył. Walezjanie zmuszali do kastracji także swoich gości. Ten sam Epifaniusz zwraca również uwagę na rozpowszechnienic w III i IV wieku praktyki autokastracji wśród pojmujących radykalnie ascezę mnichów z pustyni egipskiej ${ }^{17}$. W późniejszym okresie takie przypadki mają prawdopodobnie na myśli wspominający o mnichach eunuchach: Jan Moschos ( $\dagger$ ok. 619 r.) w tace duchowej ${ }^{18}$ oraz Leoncjusz z Neapolis w Żywocie Jana Jalmużnika, patriarchy Aleksandrii $(\dagger 616)^{19}$.

Pewną duchową inspirację dla rygorystycznie nastawionych chrześcijańskich ascetów mogło stanowić również zjawisko autokastracji kapłanów w starożytnych kultach misteryjnych. Dobrowolne pozbawianie się męskości z motywów religijnych bylo praktykowane w religiach orientalnych wśród kapłanów niektórych bóstw, np. w kulcie Isztar-Nana w Babilonie, Adonisa w Fenicji i na Cyprze, Atargatis w Syrii, Asztarte w Edessie, Afrodyty w Aphaka w Górach Libanu, Artemidy w Efezie czy Ozyrysa i Izydy w Heliopolis $w$ Egipcie $^{20}$. W cesarstwie rzymskim praktyka ta przetrwała przede wszystkim w kulcie bogini Kybele, Wielkiej Matki Bogów, wywodzącym się ze wschodniej Frygii w Azji Mniejszej ${ }^{21}$. W Rzymie kult ten został przyjęty

16 Panarion 58, 1, GCS 31, 358. Nie wiadomo nic o tej sekcie $z$ innych starożytnych źródeł. Epifaniusz czerpie wiadomości o niej z ustnych przekazów. Augustyn przytacza wzmiankę Epifaniusza i stwierdza, że nie jest w stanie nic przekazać na temat doktryny walezjan poza tym, że kastrują siebie i swoich gości, sądząc, że w ten sposób powinno się służyć Bogu: „Valesii et se ipsos castrant, et hospites suos, hoc modo existimantes Deo se debere servire. Alia quoque haeretica docere dicuntur et turpia: sed quae illa sint, nec ipse commemoravit Epiphanius, nec usquam potui reperire" (De haeresibus 37, CCL 46, 306). Niektórzy badacze podejrzewają. że taka sekta w ogóle nie istniała, por. P. Browe, Zur Geschichte der Entmannung. Eine religions-und rechtsgeschichtliche Studie, Breslau 1936, 18; Muth, dz. cyt., k. 320.

${ }^{17}$ Por. Expositio fidei catholicae et apostolicae Ecclesiae 13, PG 42, 805.

${ }_{18}$ Por. Pratum spirituale 40,165, 173, 184, PG 87/3, 2892, 3032, 3041, 3056.

${ }^{19}$ Por. Vita Ioannis Elemosynarii 23, PG 93, 1636; zob. Browe, dz. cyt., s. 21. Współczesny badacz amerykański Daniel Caner, podejrzewa, wbrew rozpowszechnionym poglądom o odosobnionych przypadkach kastracji, że stanowiły one dość rozpowszechnioną praktykę wśród wczesnych chrześcijan, zwłaszcza we wschodniej części Cesarstwa, którzy uznawali radykalny ascetyzm cielesny za istotny element chrześcijańskiej pobożności, zob. D. Caner, The Practice and Prohibition of Self-Castration in Early Christianity, VigCh 51 (1997) 396-398.

${ }^{20}$ Por. Origenes, Hexapla, PG 15, 302; Hieronymus (?), Liber hebraicorum quaestionum in Genesim 37, 36, PL 23, 995; także: Ovidius, Amores II 13, 18, zob. Browe, dz. cyt., s. 13-16.

${ }^{21}$ Zdaniem W. Burkerta, kult Wielkiej Matki Bogów pojawil się w religii greckjej - od Azji Mniejszej po południową Italię - już w okresie archaicznym, zob. W. Burkert, Starożyme kulty misteryjne, thum. K. Bielawski, Bydgoszcz. 2001, 38. 
oficjalnie w 204 r. przed Chr., jego zaś publiczne formy rozwinęły się dopiero w okresie cesarstwa od czasów Klaudiusza, a zwłaszcza w II wieku za panowania Antonina Piusa. Wielkie 12-dniowe uroczystości procesyjne odbywały się w marcu i zbiegały się ze zrównaniem wiosennym, czyli z okresem budzenia się płodności ziemi. Odtwarzano wówczas mit o Attysie ${ }^{22}$, czczonym jako bóstwo wegetacji ${ }^{23}$. Był on frygijskim pasterzem, ukochanym Kybele, która powierzyla mu nadzór nad swoją świątynią, pod warunkiem, że zachowa czystość do końca życia. Attys złamał jednak przysięgę, gdy zapałał namiętnością do nimfy Sagaridy. Wtedy Kybele zabiła nimfę, a Attys w przystępie świętego szału dokonal samokastracji przy drzewie sosny i umarł z upływu krwi. Odżył jednak dzięki zrodzonym w tej krwi fiołkom. Kaplani Kybele, zwani Gallami ${ }^{24}$, dokonywali więc samokastracji, aby upodobnić się do Attysa. W dniu 24 marca podczas celebrowania pogrzebu Attysa również wierni ranili swoje ciała, dokonując niejednokrotnie dobrowolnej samokastracji ${ }^{25}$.

Zwyczajc kultowe Gallów wzbudziły zdecydowaną krytykę w środowisku judaistycznym i chrześcijańskim. Wypowiadał się przeciw nim zhellenizowany Żyd aleksandryjski Filon ${ }^{26}$. Było to zgodne $z$ tradycją starotestamentalną,

${ }^{22}$ Mit ten miał kilka różnych wersji; rozpowszechniona w Rzymie jest najmniej skomplikowana.

${ }^{23}$ Imię „Attys” oznacza zmielony kłos, por. Philosophoumena V 8, PG 16, 3150-3151.

${ }^{24}$ Herodian (Historia Cesarstwa Rzymskiego I 11) wywodzi nazwę Gallów od rzeki Gallus we Frygii, nad którą odbywały się orgie kultowe ku czci Kybele, por. Ovidius, Fasti IV 363; Plinius, Historia naturalis V 147. Inni antyczni autorzy (Pauzaniusz, Arnobiusz) wywodzili nazwę od króla Gallosa, który, wedhug jednej z wersji mitu, był teściem Attysa. Hieronim natomiast łączy tę nazwę z plemieniem Gallów, którzy zajęli Frygię i z którego przede wszystkim pochodzili owi kapłani na terenie Cesarstwa (por. przyp. 30). Być może nieprzypadkowo nazwa owych kaplanów łączy się z lacińskim słowem „gallus” - kogut. Ptak ten był niekiedy przedstawiany na kamieniach nagrobnych Gallów, por. A. Schober, Die römische Grabsteine von Noricum und Pannonien, Wien 1923, 56 i 215. W Persji, Egipcie, a poźniej Grecji panowało przekonanie, że kogut jest zwierzęciem pełniącym rolę apotropaiczną: przepędza demony i czarnoksięzników. Istniała zasada pitagorejska, która ściśle zabraniała składania ofiary z kogutów, zob. E. Dodds, Grecy i irracjonalność, thum z ang. J. Partyka, Bydgoszcz 2002, 232. Literatura na temat kultu Kybele: $\Upsilon$. Zieliński, Religia starożytnej Grecji. Zarys ogólny. Religia hellenizmu, Wroclaw - Warszawa - Kraków 1991, 178180; M. Jaczynowska, Religie świata rzymskiego, Warszawa 1987, 197-199; M.J. Vermaseren, The Legend of Attis in Greek and Roman Art, Leiden 1966; tenze, Cybele and Attis: the Myth and the Cult, Leiden 1977; H.J. Bell, Cults and Creeds in Graeco-Roman Egypt, Liverpool 1954; R. Duthoy, Taurobolium: its Evolution and Terminology, Leiden 1969; G. Thomas, Magna Mater and Attis, ANRW II 17, 3, 1984, 1500-1535 (tam też zebrana bibliografia: s. 1280-1294); M. Eliade, Historia wierzeń $i$ idei religijnych, tłum. S. Tokarski, II, Warszawa 1994, 187-191; J.P. Roux, Krew. Mity, symbole, rzeczywistość, tłum. M. Perek, Kraków 1994, 308-310; Cybele, Attis and Related Cults. Essays in Memory of M.J. Vermaseren, ed. E.N. Lane, Leiden - New York - Köln 1996.

25 Rzekomo nawet sam cesarz Heliogabal (218-222) mial dokonać rytualnej samokastracji, wprawdzie nie jako kapłan Kybele, ale syryjskiego boga Baala, zob. Historia Augusta. Vita Heliogabali 7, 2, por. Browe, dz. cyt., s. 17.

${ }^{26}$ Por. De specialibus legibus III 37-42. 
wyrażoną w przepisie: „Nikt kto ma zgniecione jądra lub odcięty czlonek, nie wejdzie do zgromadzenia Pana" (Pwt 23, 2) ${ }^{27}$. Również św. Paweł pisząc do Galatów (Ga 5,12) - „Oby się do końca okaleczyli ci, którzy was podburzają”, robi aluzję do Gallów. Brutalność kultu Kybele byla również krytykowana przez wielu wczesnochrześcijańskich autorów, relacjonujących jego istnienie: Laktancjusza $^{28}$, Ambrozjastra ${ }^{29}$, Hieronima ${ }^{30}$, Augustyna ${ }^{31}$, Pseudo-Cypria$\mathrm{na}^{32}$, Paulina $\mathrm{z}$ Noli $^{33}$ i Prudencjusza ${ }^{34}$. Nazywali oni pogańskich bogów, domagających się tak krwawych ofiar, demonami ${ }^{35}$. Wczesnochrześcijański opór przeciw misteriom Kybele i Attysa miał nawet swojego męczennika. Był nim św. Symforian (wspominany w martyrologium 22 sierpnia), który zginął w 180 r. w Autun w Galii za odmówienie uczczenia Kybele i zelżenie jej wykastrowanych kapłanów ${ }^{36}$.

${ }^{27}$ Prawdopodobnie chodziło w tym tekście tylko o zakaz samokastracji z powodów kultowych i o niedopuszczanie kastratów do sprawowania kultu, a nie wszelkich kastracji, które mogły zdarzyć się np. wbrew woli podczas niewoli babilońskiej (trzej młodzieńcy w piecu ognistym), skoro w Iz 56, 3b-5 czytamy: „Rzezaniec także niechaj nie mówi: «Oto ja jestem uschlym drzewem». Tak bowiem mówi Pan: «Rzezańcom, którzy przestrzegają moich szabatów i opowiadają się za tym, co Mi się podoba, oraz trzymają się mocno mojego przymierza, dam miejsce w moim domu i w moich murach oraz imię lepsze od synów i córek, dam im imię wieczyste i niezniszczalne»”. Z tekstu Izajasza wynika, ze w czasach ostatecznych jakakolwiek kastracja przestanie być powodem wykluczenia ze spoleczności zbawionych, por. Mdr 3, 14.

${ }^{28}$ Por. Divinae Institutiones I 21, SCh 326, 214: „Publica illa sacra, quarum alia sunt matris deum, in quibus homines suis ipsi virilibus litant - amputato enim sexu nec viros se nec feminas faciunt $[\ldots] "$ ".

29 Por. Quaestiones Veteris et Novi Testamenti, PL 35, 2349C: „[...] ut abscisi [Galli] in mulieres transformentur [...] quos constat minis circumveniri et promissis praemiis ad hunc dolorem et dedecus cogi".

${ }^{30}$ Por. Commentarius in Osia I 4, 14, CCL 76, 44: „Hi [effeminati] sunt quos hodie Romae matri, non deorum, sed daemoniorum servientes Gallos vocant, eo quod de hac gente Romani truncatos libidine in honorem Attis, quem eunuchum dea meretrix [= Magna Mater] fecerat, sacerdotes illius manciparint. Propterea autem Gallorum gentis homines effeminantur, ut, qui urbem Romam ceperant, hac feriantur ignominia".

${ }^{31}$ Por. De civitate Dei II 7, CCL 47, 40: ,[...] in templis daemonum Galli absciderentur [...]”. Augustyn, podobnie jak Laktancjusz, Firmicus Maternus i Hieronim, byl przekonany, ze bogowie pogańscy, zwłaszcza domagający się krwawych ofiar, są demonami i zwodzą nieświadomych ludzi, por. Firmicus Maternus, De errore profanarum religionum 22, 4, CSEL 2, 112: „[...] habet ergo diabolus christos suos"; Hieronymus, Adversus Iovinianum II, 17, PL 23, 312.

32 Por. De singularitate clericorım 33, CSEL 3/3, 209: „Puto etiam de Gallis suis nobis idololatrae exprobranter insultent, qui abscindentes semet ipsos libenter excruciant, dummodo cum damno status sui simulacrorum dissimulationibus pareant". Być może jest to traktat donastycznego bpa Makrobiusza z Rzymu (363-375).

${ }^{33}$ Por. Poema 19, 185, CSEL 30, 125.

${ }^{34}$ Por. Peristephanon 10, 1064, PL 60, 524. Kosma z Jerozolimy wspomina o nich jeszcze w VIII wieku: Commentarii in s. Gregorii Nazianzeni carmina 64, PG 38, 502.

${ }_{36}$ Hieronim obdarzyl Kybele mianem ,virgo diaboli” (por. przypis nr 31 ).

${ }^{36}$ Por. Martyrologium 6, PG 5, 1466. 
Czy jednak tradycja kapłanów Kybele nic mogła stanowić pewnej duchowej inspiracji dla rygorystycznic nastawionych chrzcścijańskich ascetów? Taką możliwość sugeruje Bazyli z Ancyry, biskup semiariański z IV wieku, działający niedaleko Frygii ${ }^{37}$. Być może nie jest przypadkiem, że właśnie we Frygii, ojczystej ziemi zwyczaju sakralnej kastracji, rozwijała aż do $\mathrm{V}$ wieku swoją działalność znana sekta montanistów (zwana także katafrygianami), której czlonkowie wyróżniali się wśród chrześcijan daleko posuniętym rygoryzmem ascetycznym. Hieronim nazywa Montana rzezańcem i półmężczyzną - „abscisus et scmivirus", choć mógł on być wykastrowany wcześnicj, nie z motywów religijnych ${ }^{38}$. Zwrot ten może być zresztą tylko retorycznym zabiegiem inwektywy, często towarzyszącym wypowiedziom cholerycznie usposobionego Hieronima, użytym tu właśnie na zasadzie skojarzenia miejsca powstania montanizmu z miejscem największego rozwoju kultu Kybele ${ }^{39}$.

Pewne inspiracje pozbawiania się męskości przez chrześcijan mogły wiązać się z motywacją kastracji we wspomnianych pogańskich kultach misteryjnych. Według najbardziej rozpowszechnionych opinii, kastracja kaplanów miała być metodą zapewnienia sobie przez nich rytualnej czystości ${ }^{40}$. Stanowiła takze sposób na zjednoczenie czy wręcz utożsamienie się z bóstwem i wejście w posiadanie mocy nadprzyrodzonej ${ }^{41}$. W źródłach i literaturze przedmiotu

${ }^{37}$ Por. De virginitate 62, PG 30, 797A; zob. P. Cavallera, La „De virginitate” de Basile d'Ancyre, RHE 6 (1905) 5-14. Niektórzy badacze łączą rzekomą kastrację Orygenesa z inspiracjami płynącymi z kultu Attysa, zob. S. Martinelli, Origene e il mito di Attys „,Mondo classico" 1 (1931) 49-54. Orygenes wprawdzie zaznacza w Contra Celsum, że kulty misteryjne rozpowszechniły się

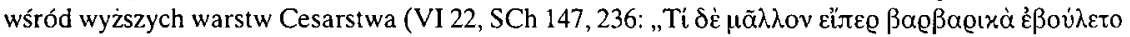

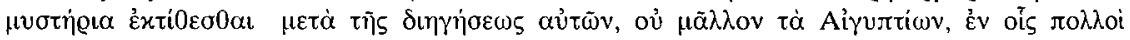

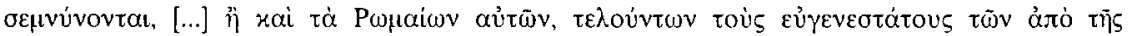

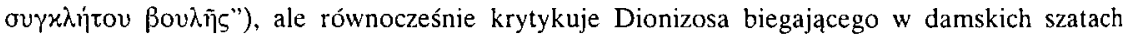

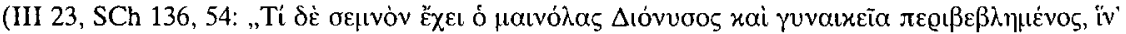

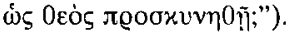

38 W.H.C. Frend (The Rise of Christianity, London 1984, 253) wysunął nawet hipotezę, ze Montan mógl być „perhaps a one-time priest of Cybele".

${ }^{39}$ Por. Epistulae 41, 4, CSEL 54, 314; zob. G.M. Sanders, Gallos, RACh VIII 1027; P. de Labriolle, La crise montaniste, Paris 1913, 20; A.T. Fear, Cybele and Christ, w: Cybele, Attis and related Cults. Essays in Memory of M.J. Vermaseren, ed. E.N. Lane, Leiden - New York - Köln 1996, 38-39.

${ }^{40}$ Takie stanowisko zajmuje A.D. Nock, Eunuchs in Ancient Religion, w: Essays on Religion and the Ancient World 1, red. Z. Stewart, Cambridge 1972, 6-15. Przeciwnego zdania jest A. Rousselle, Porneia: On Desire and the Body in Antiquity, Cambridge 1988, 125-127. Warto zwrócić uwagę, że Izydor z Sewilii wyprowadzal etymologię przymiotnika „castus” właśnie od rzeczownika „castratio”: „Castus primum a castratione nuncupatur” (Etymologiae X 33, PL 82, $371)$.

${ }^{41}$ Focjusz wspomina w Bibliotece (242) o filozofie Damaskiosie z Damaszku, który w Żywocie filozofa Izydora opisuje swój sen podczas pobytu w Hierapolis we Frygii, kiedy to wydawało mu się, że jest Attysem i na rozkaz Matki Bogów obchodzi uroczyście święto Hilaria, zapowiadające wyzwolenie z Hadesu, por. M. Meslin, Réalités psychiques et valeurs religieuses dans les cultes 
można znaleźć jeszcze inne propozycje umotywowania kastracji kultowej Gallów ${ }^{42}$. Chciałbym zwrócić uwagę jedynie na dwa spośród nich, ponieważ mogły one być inspiracją dla chrześcijan, a przez niektórych badaczy były odnoszone wprost do Orygenesa.

Po pierwsze, akcentuje się współcześnic aspekt eschatologiczny w motywacji kultowej kastracji kapłanów w kultach misteryjnych ${ }^{43}$, na co wskazują teksty gnostyckie. W Philosophoumena przypisywanych Hipolitowi znajdujemy następujące przckonanie gnostyckiej sekty naaseńczyków ${ }^{44}$ :

orientaux (I-IV siècles) „Revue historique” 252 (1974) 296. Zarówno Seneka, jak i Tertulian zauważają, że ludzie, którzy okaleczali swoje ciała, uważali że nabywają w ten sposób boskiej mocy, por. Seneca, De vita beata 26, 8: „Cum aliquis secandi lacertos suos artifex brachia atque umeros suspensa manu cruentat [...] divinum esse eum [...] affirmatis"; Tertullianus, Apologeticum 23,3, CCL 1, 130: ,[...] alia vis pronuntietur in eo, qui lacertos, alia in eo. qui sibi gulam prosecat", zob. Caner, dz. cyt., s. 399. Zdaniem Kuefnera, autora najnowszego, zawierającego skądinąd pewne interpretacyjne naduzycia, opracowania dotyczącego wczesnochrześcijańskiego eunuchizmu (zob. przypis nr 4), wśród pierwszych pokoleń wyznawców Chrystusa mogły zdarzyć się w dobrej wierze przypadki zestawiania prokastracyjnej motywacji zaczerpniętej z kultów misteryjnych $\mathrm{z}$ zachętą Jezusa do praktykowania dobrowolnego wyrzeczenia się swojej męskości. ponieważ Zbawiciel nie sprecyzowal, o jaki rodzaj eunuchizmu chodzi.

12 Lukrecjusz tłumaczył, że Gallowie kastrują się, ponieważ podobnie jak Attys, pogwalcili majestat Magna Mater. $Z$ powodu okazania wobec niej niewdzięczności, nie są godni wydać na świat potomstwa, zob. Lucretius, De natura rerum II 615. Na początku XX wieku J.H. Rose i A.B. Cook wysunęli dyskusyjną hipotezę, że motywem kastracji jest oddanie przez kapłanów Kybele wlasnych „vires” w celu umocnienia energii witalnej bogini. Hipoteza ta spotkała się z krytyką. gdyż byloby czymś paradoksalnym, że bogini Matka urodzaju była obsługiwana przez ludzi pozbawionych zdolności zapłodnienia i żeby potrzebowała umocnienia z ich strony, zob. Meslin, dz. cyt., s. 297; Nock, dz. cyt., s. 7. A.D. Nock w latach trzydziestych zmodyfikowal tę hipotezę, podejrzewając, że podstawą kastracji kapłanów w kulcie bóstw płodności mogła być zasada "do ut des”, rozumiana jako konieczność oddania w ofierze bogini wlasnej plodności w celu otrzymania w zamian błogosławieństwa urodzaju. Krew kastrata dokonującego rytualnego zabiegu spadała na ziemię i użyźniała ją. Takie rozumowanie potwierdza wzmianka u Euzebiusza (Vita Constantini IV 25, PG 20, 1172) o wydanym przez Konstantyna zakazie kastracji kapłanów Nilu, który wywołał przerażenie, iż rzeka pozbawiona ofiar przestanie nawadniać i użyźniać pola, zob. Nock, dz. cyt., s. 12-13. W. Burkert na podstawie tekstów Juliana Apostaty i Salustiusza wysnuł hipotezę, że kastracja kapłanów Kybele miała być obrazem ważnego etapu w procesie ewolucji bytu: ,Jedyny, stwarzając jako ojciec świat duchowy i psychiczny, kontynuuje dzieło stworzenia aż po świat materialny; w koŕcu jednak musi się zatrzymać, żeby ów świat nie zatracił się w nieograniczonej obfitości. Rozwój musi nagle zmienić się w regres: tym właśnie jest obcięcie genitaliów. Prokreacja zostaje zatrzymana, a bytowi przywrócona zostaje bezpieczna stabilność, kiedy zwraca się on ponownie ku swym początkom", \%ob. Burkert, dz. cyt., s. 154. Plotyn (Emmeadae 3, 6. 19, 29) czyni z Meter, otoczonej przez wykastrowanych ,galloi”. personifikację materii, która jest bez-

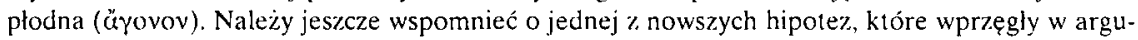
mentację nawet teorię psychoanalizy. M. Meslin podejrzewa, że u podłoża tego rytu leży kompleks kastracji rozumiany przez Brunona Bettelheima jako glębokie pragnienie pewnych mężczyzn do bycia także kobietami, co znajdowato wyraz w otrzymywaniu przez poświęconych Kybele kastratów damskich szat.

${ }^{43}$ Por. Meslin, dz.. cyt., s. 303-304. 
„Attys wykastrował się [...], aby przejść do wiecznej egzystencji, tam gdzie nie ma kobiety i mężczyzny, ale jest nowe stworzenie, nowy człowiek, który jest dwuplcio-

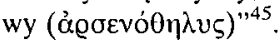

Podobne stanowisko, głoszące, że powrót do Bożego Królestwa wymaga zjednoczenia $w$ jednym bycie szczególnych mocy, związanych $\mathrm{z}$ oboma rodzajami płci, występuje w Ewangelii św. Tomasza ${ }^{46}$, używanej zresztą przez naaseńczyków, a nawiązania do niego znajdują się w Aktach Filipa ${ }^{47}$, Aktach Toma$s z a^{48}$, Ewangelii Egipcjan oraz w krytykowanym przez Klemensa Aleksandryjskiego traktacie O powściagliwości czyli o kastracji Juliusza Kasjana ${ }^{49}$ i w zebranych również przez Klemensa Excerptach z gnostyka Teodota ${ }^{50}$. Rozpowszechnienie powyższego poglądu w środowisku egipskich gnostyków musiało

${ }^{44}$ Por. K. Rudolph, Gnoza. Istota $i$ historia późnoantycznej formacji religijnej, tlum. G. Sowiński, Kraków 1995, 79-80: „Kto mówi, że wszechrzeczy składają się z jednej [zasady], ten błądzi; kto mówi, że z trzech, mówi prawdę i daje [trafne] wyjaśnienie wszechrzeczy" - tak brzmi według Hipolita podstawowa teza naaseńczyków. Kierunek ten, który swą nazwę otrzymał ze względu na swe upodobanie do węża (hebrajski nachasch, zgrecyzowany naas), mówi o „Uprzednio-bedącym”, o „Samopowstałym” oraz o chaosie, do którego dochodzi jeszcze demiurg jako „czwarta sila”, imieniem Esaldaios. Ta ostatnia, bez pomocy i wiedzy Pierwszego, stworzyła kosmos "nicość", a przy tym - co tylko zakladamy - zamknęla w chaosie ruchomą pośrednią zasadę, duszę świata czy też (wewnętrznego) człowieka (anthropos). Głównie losom tej cząstki poświęca swą uwagę dłuższe pismo doktrynalne, tak zwane Kazanie naaseńczyków [...]".

45 Philosophoumena V 7, PG 16, 3131.

46 Por. Logion 22-23, w: L'Évangile selon Thomas, ed. J.E. Ménard, Nag Hammadi Studies, $\mathrm{V}$, Leiden 1975, 60-61 i 113-116.

${ }^{47}$ Por. Acta Philippi 140, CCAp 11, 403-406.

48 Acta Thomae 129, ed. A.F.J. Klijn: The Acts of Thomas, Supplements to Novum Testamentum, V, Leiden 1962, 134.

49 Por. Clemens Alexandrinus, Stromata III 13, 91-92, GCS 52, 238, thum. J. NiemirskaPliszczyńska: Kobierce, I, Warszawa 1994, 282-283; „W swym traktacie [...] Kasjan doslownie mówi tak: «Niech nikt nie opowiada, że, jakoby pożycie płciowe zostało ustanowione przez Bo. ga, niby wnjoskując $z$ tego, że mamy takie części ciała, iż kobieta w ten sposób jest zbudowana, a mężczyzna inaczej, mianowicie kobieta do przyjmowania, a mężczyzna do wprowadzania w nią nasienia. Gdyby bowiem taki plan obmyślił sam Bóg, do którego zdążamy, to nie oceniałby przecież rzezańców jako szczęśliwych, a prorok nie powiedziałby o nich, że nie sq̨ drzewem nie przynoszqcym owoców (por. Iz 56,3), przeniósłszy obraz drzewa na czlowieka, który pod wplywem takiego poglądu wyrzeka się męskości z wlasnego postanowienia». I jeszcze walcząc dalej w imię swego bezbożnego mniemania dodaje: «Jak można nie uznawać Zbawiciela za przyczynę sprawczą świata, jeśli nas przemienił, uwolnił od błędu i od związku płciowego części ciała męskich i żeńskich»? Pod tym względem głosi Kasjan zasady bliskie teorii Tacjana. Sam zaś wyszedı ze szkoły Walentyna. Dlatego mówi: “Gdy Salome dopytywała się, kiedy będzie wiadome to, czego usilowała się dowiedzieć, rzekł Pan: 'gdy podepczecie stopami zasłonę wstydliwości i gdy dwoje stanie się jednym, a męski pierwiastek z żeńskim nie będzie ani męski, ani żeński’». Po pierwsze oto nie zostało to powiedziane w czterech przekazanych nam Ewangeliach, lecz w tej, która jest zwrócona do Egipcjan. Po drugie Kasjan, wedle mego zdania, nie wie, że przez męską namiętnośc rozumiany jest gniew, a przez żeńską pożądanie".

${ }^{\text {so }}$ Por. Excerpta ex Theodoto 64, SCh 23, 186. 
być znane Orygenesowi i mogło wpłynąć na jego koncepcję ciała zmartwychwstałego. Hieronim w Apologii przeciw Rufinowi sugeruje nawet $\mathrm{z}$ oburzeniem, że Orygenes był przekonany, iż ciała ludzkie zmartwychwstaną bez męskich i żeńskich cech płciowych ${ }^{51}$. Takie podejrzenie może istotnie wywoływać zachowany tekst z Komentarza do Ewangelii św. Mateusza 17, 30. Orygenes polemizuje w nim ze stanowiskiem saduceuszy, którzy nie wierzyli w zmartwychwstanie, ponieważ uważali, że stosunki małżeńskie i rodzinne musiałyby być w nowym życiu podobne do ziemskich. Aleksandryjczyk stwierdza, ze w przyszłym życiu nie będzie współżycia cielesnego i prokreacji, a przekształcone ciala poniżone (por. Flp 3,21) staną się eteryczne i świetliste. Sugeruje też przy okazji, że konsekwentnie zmartwychwstałe ciało nie powinno mieć narządów płciowych, ponieważ Pan Bóg nie stwarza niczego zbytecznego. Kontekst wypowiedzi wskazuje jednak, że Aleksandryjczyk, zgodnie ze swoim zwyczajem, nie prezentuje tego stanowiska jako pewnik, lecz jako glos w dyskusji ${ }^{52}$.

Drugi sposób interpretacji kastracji kultowej kapłanów Kybele, na który chciałbym zwrócić uwagę w związku $\mathrm{z}$ ewentualnym wpływem na postawę Orygenesa, pochodzi z hymnu $O$ Matce bogów cesarza Juliana Apostaty $(362-363)^{53}$. Jest to interpretacja teurgiczna w duchu neoplatońskim ${ }^{54}$. Julian dostrzega w micie o Attysie ilustrację koncepcji filozoficznej, związanej z przekonaniem, że warunkiem osiągnięcia zbawienia jest wyzwolenie $\mathrm{z}$ więzienia materii. W myśl interpretacji Juliana idee skonkretyzowane w materii, która jest ich więzieniem, tęsknią za powrotem do pierwotnej formy swego istnienia $^{55}$. Attys przedstawia zasadę twórczą, która wbrew woli Matki bogów nie chce być płodna tylko w świecie idei i skłania się ku prokreacji form materialnych. Matka bogów pragnąc przeszkodzić Attysowi w całkowitym zepsuciu i zagubieniu się w materii, doprowadza go do pozbawienia się męskości. Symbolizuje ono ograniczenie dekadencji materialnej, jakiej podlega zasada twórcza i oznacza jej powrót do świata idealnego ${ }^{56}$. W 1931 r. S. Martinelli wysunął dość ryzykowną hipotezę, że młody Orygenes jako słuchacz wykładów Ammoniusza Sakkasa, w których uczestniczył również Plotyn ${ }^{57}$, pozostawał pod sil-

51 Por. Hieronymus, Apologia contra Rufinum II 5, CCL 79, 37.

52 Por. H. Crouzel, Orygenes, thum. J. Margański, Bydgoszcz 1996, 334-335.

53 Por. G. Rochefort, L'empereur Julien oeuvres complètes, II/2, Paris 1964, 94-102; Sz. Olszaniec, Julian Apostata jako reformator religijny, Kraków 1999, 79-92 i 98-99.

${ }^{54}$ Teurgia jest religijno-filozoficzną postacią magii, polegającą na skłanianiu bóstwa do wykonania jakichś działań albo do powstrzymania się od nich.

55 Por. Jaczynowska, dz. cyt., s. 222-223; M. Simon, Cywilizacja wczesnego chrześcijaństwa I-IV w., thum E. Bąkowska, Warszawa 1979, 84; Dodds, dz. cyt., s. 225-229.

${ }^{56}$ Por. G. Negri, L'imperatore Giuliano Apostata. Studio storico, Varese - Milano 1954.

57 Por. Martinelli, art. cyt., s. 53-54; często błędnie przedstawia się Orygenesa jako neoplatończyka, podczas gdy jest on typowym przedstawicielem chrześcijańskiego średniego platonizmu; zob. H. Crouzel, Origène et Plotin, Comparaisons doctrinales, Paris 1991; E. Des Places, Platonismo e tradizone cristiana, Milano 1976. 
niejszym wpływem platońskich idei filozoficznych niż samego chrześcijaństwa i mógł lączyć owe idee $z$ teurgiczną interpretacją misteriów Kybele i Attysa. W tych właśnie inspiracjach upatruje Martinelli istotny motyw Orygenesowej kastracji. Hipotezy tej nie sposób zweryfikować i nie została ona podjęta przez późniejszych badaczy. Komentując w swoich dziełach egzegetycznych błędne interpretacje fragmentu Mt 19, 12 przez chrześcijan, Orygenes nigdzie nie powołuje się na podobne inspiracje. Nie czyni tego również, wzmiankując w Contra Celsum istnienie i popularność orientalnych kultów misteryjnych wśród współczesnych mu pogan. Ponadto należy zwrócić uwagę, że Orygenes uczęszczał na wykłady Ammoniusza najprawdopodobniej już po ukończeniu 20 lat, a więc po dokonaniu autokastracji.

Przyjrzymy się obecnie, co na temat występowania wśród chrześcijan II i III wieku zjawiska kastracji pisze sam Orygenes. Otóż wspomina on, że widział ludzi, którzy odważyli się na ten czyn, a także takich „którzy [...] potrafią [do niego] skłonić co gorętszą duszę wierząca, lecz nie bardzo słuchającą rozumu"58. Orygenes podaje też główne uzasadnienie samokastracji rozpowszechnione wśród niektórych chrześcijan. Było nim literalnie rozumiane stwierdzenie z Ewangelii św. Mateusza 19, 12 o pozbawieniu siebie samego cielesnej zdolności do małżeństwa ze względu na Królestwo niebieskie ${ }^{59}$, a także wypowiedzi niechrześcijańskie rozpowszechnione jednak w środowisku chrześcijan. Jedną z nich byla sentencja 13. z księgi Sentencji niejakiego Sekstusa. Pochodziła ona ze środowiska pitagorejskiego I wieku przed Chr. i została prawdopodobnie zredagowana na nowo w II wieku przez chrześcijan ${ }^{60}$. Jak pisze

58 Commentarius in Matthaeum XV 3, PG 13, 1257C, tłum. K. Augustyniak, ŹMT 10, 232.

59 W zachowanych źródłach patrystycznych trudno znaleźć jakieś inne motywy autokastracji poza interpretowanymi dosłownie tekstami z Ewangelii św. Mateusza 5, 27-30 i 19, 10-12. Do istniejącej rzekomo w pierwszych wiekach teologii kastracji nawiązywali pod koniec XVIII wieku (oficjalnie od 1771 r.) czlonkowie prawosławnej sekty skopców. Jej założyciel chłop rosyjski Kondratij Seliwanow twierdzit, że do początków IV wieku, czyli do czasów antykastracyjnego prawodawstwa cesarza Konstantyna Wielkiego, praktyka kastracji była rozpowszechniona wśród chrześcijan, ponieważ miały przemawiać za tym szczególne przesłanki teologiczne. Otóż zdaniem Seliwanowa, Bóg Ojciec posłal swojego Syna, aby uwolnił ludzi od życia płciowego i umożliwił im życie w czystości i świętości. Starotestamentalne obrzezanie miało być zapowiedzią wielkiej tajemnicy kastracji, Chrystus podczas chrztu w Jordanie zostal wykastrowany przez Jana Chrzciciela, a podczas Ostatniej Wieczerzy dokonał tego obrzędu na swoich uczniach. Według skopców pierwotne ciała ludzkie były eteryczne i pozbawione organów płciowych, które pojawily się dopiero jako następstwo pierworodnego grzechu. Tylko przez kastrację, rozumianą jako chrzest ognia i przyjęcie Bożego znamienia, można stać się w pełni czystym i osiągnąć zbawienie. Żadne zachowane źródła nie potwierdzają jednak istnienia tak daleko posuniętej prokastracyjnej wczesnochrześcijańskiej teologii, poza wspomnianym już poglądem o eteryczności i bezpłciowości ciał ludzkich po zmartwychwstaniu, pojawiającym się u gnostyków oraz „implicite" u Orygenesa, por. Szumowski, dz. cyt., 10-16; S. W. Bulhakow, Nastolnaia Kniga dla Swiaszczenno-Cerkowno-Stuzitieliej, Moskwa 1993, 1658; H. Masson, Stownik herezji w Kościele katolickim, Katowice 1993, 267.

${ }^{60} \mathrm{H}$. Chadwick przytacza dyskusję badaczy nad tożsamością Sekstusa, uważanego przez. jednych za filozofa greckiego z nurtu pitagorejskiego z przełomu er (J. Gildemeister, E. Preus- 
Orygenes, dzieło to było wykorzystywane jako wiarygodne przez wielu chrześcijan. Interesująca nas sentencja brzmi:

,Jeśli jakaś część ciała pobudza cię do niepowściągliwości, odrzuć ją; lepiej bowiem bez niej żyć w czystości niż z nią niegodziwie" ${ }^{\text {"1 }}$.

Drugą inspiracją dla chrześcijańskich kastratów mogła być, zdanicm Orygenesa, opinia wybitnego żydowskiego komentatora Ksiąg starotestamentalnych Filona Aleksandryjskiego „że lepiej pozbawić się zdolności do małżeństwa niż pożądać nieprawych związków ${ }^{62}$.

Zachowane źródła potwierdzają nie tylko fakt występowania kastracji wśród chrześcijańskich ascetów pierwszych wieków (choć nie należała ona do zjawisk chwalonych w taki sposób, jak to ujął Euzebiusz w swej relacji o pierwszej reakcji na czyn Orygenesa), ale także zawierają ślady świadczące o przyjmowaniu przez kastratów święceń kaplańskich. Philosophoumena Hipolita wspominają o posłańcu Marcji, konkubiny cesarza Kommodusa (180-192), przyjaciela późniejszego papieża Kaliksta (217-222), starcu o imieniu Hiacynt, który był równocześnie prezbiterem i eunuchem ( $\sigma \pi \alpha \dot{\delta} \omega \nu \pi \varrho \varepsilon \sigma \beta u ́ \tau \varepsilon-$ Q०5) ${ }^{63}$. Można wprawdzie przetłumaczyć powyższe sformułowanie także jako „stary kastrat", ale Leclercq w znanym słowniku starożytności chrześcijańskiej opowiada się zdecydowanie za przekladem „kaplan kastrat" ${ }^{\text {"64 }}$. Euzebiusz nazywa też eunuchem znanego apologetę z końca II wieku Melitona, biskupa Sardes ${ }^{65}$. W tym ostatnim przypadku nie jest wykluczone użycie terminu „eunuch" w znaczeniu przenośnym na określenie „człowieka bezżennego", a nie w znaczeniu dosłownym fizycznego rzezańca, ale do tej kwestii powrócę

chen), przez innych za chrześcijanina (J. Gwynn), przez jeszcze innych za poganina, którego dzieła zrewidowali pierwsi chrześcijanie (A. Harnack). Sam Chadwick skłania się ku tej ostatniej koncepcji. Malo prawdopodobne jest przekonanie Rufina z Akwilei, że autorem zbioru 451 sentencji jest papież Sykstus II (257-258). Istnienie konkretnego filozofa pitagorejskiego o tym imieniu jest prawdopodobnie wymysłem Hieronima, gdyż żadne inne źródło nie wspomina o takim autorze, por. F. De Paola, Le Sentenze di Sesto, Milano 1937; H. Chadwick, The Sentences of Sextus. A Contribution to the Early Christian Ethics, Cambridge 1959; F. Wisse, The Sentences of Sextus, Leiden 1977, 454-459, Muth, dz. cyt., k. 321. Zupelnym błędem jest utożsamienie autora sentencji z Sekstusem Empirykiem (lekarzem, filozofem i krytykiem sceptycyzmu z przełomu II i III wieku), jak tego dokonal wydawca polskiego przekładu Orygenesowego Komentarza do Ewangelii św. Mateusza, zob. Orygenes, Komentarz do Ewangelii św. Mateusza, thum. K. Augustyniak, wstęp i oprac. E. Stanula, Kraków 1998, s. 232, przyp. 2.

${ }^{61}$ Cyt. za: Origenes, Commentarius in Matthaeum XV 3, PG 13, 1260AB, tłum. K. Augustyniak, ŹMT 10, 232.

${ }^{62}$ Cyt. tamże, s. 233 = Philo, Quod deterius potiori insidiari soleat 176. To stanowisko Filona może dziwić, gdyż w innych miejscach swych dzieł interpretuje on "eunuchizm” alegorycznie i wyśmiewa Gallów - wykastrowanych kapłanów Kybele.

${ }^{63}$ Por. Philosophoumena IX 12; PG 16, 3381-3383.

${ }^{64}$ Por. H. Leclercq, Castration, DACL II/2 2369-2372.

${ }^{65}$ Por. HE V 24, SCh 41, 68. 
omawiając argumentację przeciw kastracji Orygenesa. Nie należy też zapominać, że chrześcijanie w pierwszych wiekach byli również kastrowani podczas prześladowañ $^{66}$, a wielu późniejszych chrześcijan i duchownych mogło zostać przymusowo kastratami w młodości jeszcze przed swym nawróceniem ${ }^{67}$.

Od poł. II wieku zaczynają się mnożyć wypowiedzi antykastracyjne w pismach pisarzy wczesnochrześcijańskich (o czym powiem w dalszej części artykułu), ale najstarsze znane nam oficjalne kościelne prawo antykastracyjne zostało wydane dopiero przez Sobór Nicejski w 325 r., a więc równocześnie z zaostrzeniem państwowej kodyfikacji antykastracyjnej przez Konstantyna Wielkiego $^{68}$. Formułuje ono wyraźny zakaz udzielania święceń kapłańskich

${ }^{66} \mathrm{O}$ tego rodzaju kastracjach wspomina kanon 21 Kanonów Apostolskich, zezwalając na sakrę biskupią takiego przymusowego kastrata - męczennika.

67 We wczesnochrześcijańskich martyrologiach widnieje wiele imion eunuchów, którzy najprawdopodobniej zostali wykastrowani w młodości (zapewne bez własnej woli), aby mogli bezpiecznie pełnić funkcję strażników haremów lub zajmować dworskie urzędy. W rzymskim martyrologium należą do nich: Nereus i Achilles (12 maja, koniec I w.), Colocerus i Parthenius (19 maja, za Decjusza), Prothus i Hiacynthus (11 września, za Galiena) i Indes (28 grudnia, za Dioklecjana) oraz wyznawca prezbiter Tygriusz, zmarły w $406 \mathrm{r}$. na wygnaniu (12 stycznia). Greckie martyrologium wspomina natomiast Boethazata (20 listopada) i Azata (14 kwietnia) umęczonych przez Persów. W Martyrologium Hieronymianum wspomina się (11 marca) św. Gorgoniusza, który poniósł śmierć za Dioklecjana w Nikomedii, zob. Browe, dz. cyt., s. 20; B. de Gaiffier, Palatins et eunuques dans quelques documents hagiographiques, AnBol 75 (1957) 17-46.

68 Jeśli chodzi o stosunek prawa rzymskiego do kastracji z motywów religijnych, to zachowane przepisy nie mówią „expressis verbis" o zakazie kastracji Gallów, nie poruszają też wyraźnie problemu kastratów, którzy z własnej woli dokonywali sami na sobie tego zabiegu, por. Rousselle, dz. cyt., s. 126. Przyjmuje się, że oficjalnie była dopuszczalna samokastracja tylko frygijskich Gallów, którzy musieli płacić specjalny podatek, wprowadzony prawdopodobnie za rządów Klaudiusza, por. Sanders, dz. cyt., k. 1003. M. Meslin i A.T. Fear podkreślają, że od I wieku przed Chr. aż do końca starożytności termin „gallus”, mimo iż oznaczal kapłanów kultu Kybele, był równocześnie synonimem „eunuchus cinaedus”, czlowieka o wstrętnych obyczajach, por. Martialis, Epigramata III 91; Apuleius, Metamorphoseis VIII 29; Prudentius, Peristephanon X 1073; Lactantius, dz. cyt., I 21, 6; Augustinus, De civitate Dei VII 24, zob. Meslin, dz. cyt., s. 296-297; Fear, dz. cyt., s. 47; Nock, dz. cyt., s. 14. Gallowie byli wyłączeni z praw obywatela rzymskiego, por. Suetonius, Vita Domitiani 7. Klaudiusz zezwolit jedynie na obywatelstwo rzymskie ,archigallusa" pod warunkiem, że nie będzie wykastrowany, zob. Fear, dz. cyt., s. 47. Przetrwala wzmianka w Vita Constantini (IV 25 , PG 20,1172) Euzebiusza o wydanym przez cesarza nakazie usunięcia wszelkich androgynów, w tym wykastrowanych kapłanów, oddających cześć Nilowi w egipskiej Aleksandrii. Prawdopodobnie $z$ czasów panowania Hadriana pochodzi zakaz obrzezania, złagodzony przez jego następcę Antonina Piusa, który dopuścił je za specjalnym pozwoleniem w przypadku Żydów oraz kapłanów egipskich, ale podtrzymał zakaz wobec Arabów i Samarytan, por. J. Beaujeu, La religion romaine à l'apogée de l'empire, I. La politique religieuse des Antonins (96-192), Paris 1955, 259. Trzeba pamiętać, że obrzezanie uchodziło w opinii Rzymian najprawdopodobniej za zabieg pokrewny kastracji (świadczy o tym wzmianka u Eliusza Spartianusa w Historia Augusta, gdzie określił on czynność obrzezania zwrotem „mutilare genitalia”), zob. Spartianus, Historia Augusta. Vita Hadriani 14, 2; por. E.M. Smallwood, The Legislation of Hadrian and Antoninus Pius against Circumcision, „Latomus” 18 (1959) 336 i 340. Natomiast już od panowania Domicjana zaczęło się rozwijać prawodawstwo antykastracyjne, skierowane przeciw rozpowszechnionej praktyce trzebienia nie- 
dobrowolnym kastratom (wyjątek czyni się dla okaleczonych przez lekarzy podczas choroby lub wykastrowanych przez barbarzyńców oraz dla okaleczonych przez swoich panów, a uważanych za godnych). To oficjalne stanowisko Kościola będzie potem niezmiennie podtrzymywane ${ }^{69}$. Wielu badaczy sądzi, że powyższy kanon jest spóźnioną odpowiedzią na „,casus” Orygenesa ${ }^{70}$.

wolników z dwóch innych powodów: „libidinis vel promercii causa” (prawnik Marcjan - III wiek; Digesta XLVIII 8,3,3), czyli w celu umożliwienia bezpiecznego zaspokajania cielesnego pożądania oraz dla handlu kastratami. W tym miejscu należy się wyjaśnienie, że w Rzymie odróżniano dwa rodzaje niewolników-eunuchów (exoleti, pueri delicati): wykastrowanych zupełnie (castrati), czyli takich, którzy nie mieli zdolności ani płodzenia (facultatem generandi) ani współżycia (facultatem coeundi) oraz wykastrowanych niezupełnie (spadones), czyli takich, którzy mieli wycięte tylko jądra, a zachowany członek, nie mogli więc płodzić, ale zachowywali zdolność współżycia, zob. Szumański, dz. cyt., s. 5. Ci ostatni byli poszukiwani do wyuzdanej rozpusty, zaspokajali erotyczne żądze rzymskich kobiet, dając gwarancję wyeliminowania njechcianej ciąży, a także służyli do zaspokajania skłonności homoseksualnych. Pełni kastraci natomiast byli najlepszymi strażnikami moralności kobiet, gwarantowali bowiem, że podczas nieobecności męża w domu nie dojdzie do zdradzenia go przez niewierną małżonkę. Zapoczątkowane przez Domicjana represje karne zakazujące dokonywania kastracji i lagodzące ceny wykastrowanych niewolników (spadones), pozostających u ich sprzedawców, zostały zaostrzone za Hadriana (117-138). Odtąd sprawcy kastracji, czyli dokonujący jej oraz pacjent, jezeeli na nią się dobrowolnie zgodził, podlegali „lex Cornelia de sicariis", zgodnie z którym karą była śmierć dla niewolników i wolnych ",humiliores" oraz deportacja na wyspę i konfiskata majątku dla wolnych ,honestiores” (Digesta XVIII 8, 4, 2), por. K. Amielańczyk, Reskrypty cesarza Hadriana w sprawach karnych, w: Dzieje wymiaru sprawiedliwości, red. T. Maciejewski, Koszalin 1999, 21-31. Następne zaostrzenie prawa antykastracyjnego miało miejsce za Konstantyna Wielkiego (306-337). Główną karą miała być śmierć dla sprawcy kastracji oraz konfiskata wykastrowanego niewolnika, a nawet domu, gdzie dokonano tego czynu za wiedzą właściciela, który zataił sprawę. Kolejne zaostrzenie pochodzi od cesarza Leona, który zabronił handlu kastratami pochodzącymi z terytorium Cesarstwa Rzymskiego. Ostatecznej nowelizacji prawa antykastracyjnego dokonał cesarz Justynian w 558 r. (nowela 142), który zakazal okaleczania niewolników nawet barbarzyńcom, u których Rzymianie zaopatrywali się w kastratów i wprowadził niehumanitarną odstraszającą karę „talionu”, czyli również kastracji, połączoną z konfiskatą majątku i wygnaniem wszystkich uczestników procederu: zleceniodawcy i wykonawcy operacji, handlarza i sporządzającego umowę kupna-sprzedaży, por. K. Amielańczyk, Prakılyka kastrowania niewolników i jej zakazy w prawie rzymskim, (mps), b. m. i r. w. Mimo tak ostrych sankcji nie udało się całkowicie wyeliminować plagi kastracji na terenie Cesarstwa Rzymskiego.

${ }^{69}$ Por. Concilium Nicaeanum can. 1, tłum. T. Wnętrzak, w: Dokumenty soborów powszechnych, red. A. Baron - H. Pietras, I, ŹMT 24, Kraków 2001, 26-27: „Jeśli ktoś został okaleczony

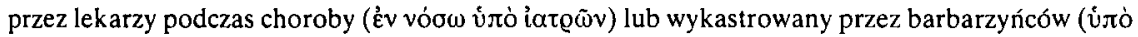
$\beta \alpha \varrho \beta \alpha ́ \varrho \omega v)$, ten niech pozostanie $w$ gronie duchownych ( $\dot{\varepsilon} v \tau \hat{\omega} x \lambda \dot{\eta} \varrho \omega)$. Lecz ten, kto będąc

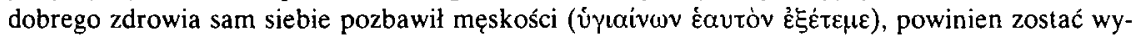
kluczony z grona duchownych, do którego już należał. Od tej chwili nie należy wyświęcać żadnego $z$ tych, którzy w ten sposób postępują. Jest jednak oczywiste, że to, co powiedziano wyżej, dotyczy

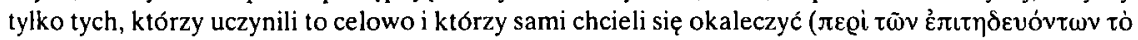

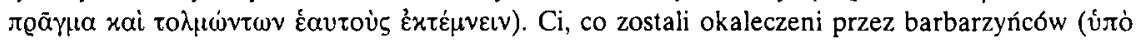

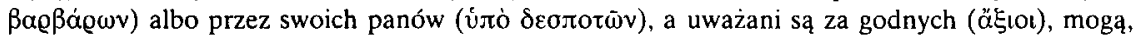
zgodnie z kanonem, zostać do stanu duchownego dopuszczeni".

${ }^{70} \mathrm{Na}$ ten związek miałoby wskazywać stwierdzenie Euzebiusza o uznaniu przez biskupa Demetriosa czynu Aleksandryjczyka za podstawowa przeszkodę w wykonywaniu przez niego 
Wspomniany kanon I Soboru Nicejskiego, dotyczący tylko kwestii święceń kapłańskich udzielanych kastratom, został w prawodawstwie kościelnym wkrótce uzupełniony przepisem wyraźnic zakazującym samokastracji osób świeckich. Pojawia się on w zredagowanych ok. 381 r. w środowisku syryjskim Kanonach Apostolskich (obowiązujących w Kościele wschodnim od 692 r.), nawiązujących z pewnością do wcześniejszej tradycji ustnej, i zawicra podstawową motywację sformułowania zakazu. W kanonie 24. tego zbioru czytamy:

„Świecki, który wykastruje się, ma być ekskomunikowany na 3 lata, ponieważ spiskował przeciw własnemu życiu"

Dwa wcześniejsze kanony, wykluczające dobrowolnych kastratów zarówno spośród kandydatów do przyjęcia święceń, jak i z grona duchowieństwa, jeżeli dopuścili się takiego czynu jako kapłani, nazywają ich samobójcami i nieprzyjaciólmi Bożcgo stworzenia. Kanon apostolski (24) powtarzają następnie Konstytucje apostolskie oraz perski synod nestoriański z 576 roku $^{72}$. Stanowisko Soboru Nicejskiego znalazło swoją konsekwentną kontynuację w późniejszym prawodawstwie epoki patrystycznej; świadczą o tym m.in. kanon 7. synodu w Arles $(452)^{73}$ i kanon 21. św. Marcina $\mathrm{z} \mathrm{Bragi}^{74}$. Mimo tak wyraźnych

funkcji kapłańskich, por. HE VI 8, 5, SCh 41, 96. Szerzej pisze o tym w IX wieku patriarcha Focjusz w swojej Bibliotece, powołując się na Apologię Orygenesa pióra Pamfila. Zgodnie z przekazem Focjusza, po synodzie w Aleksandrii w 231 r., na którym postanowiono ,usunąć Orygenesa

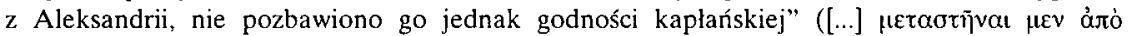

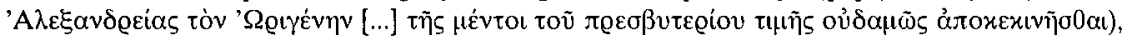
oburzony Demetrios przy udziale grupy biskupów egipskich podpisał akt, który miał pozbawić

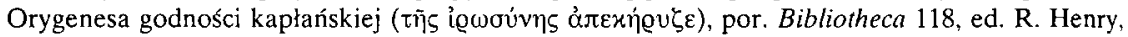
Paris 1960, 91-92. Jak zauważył H. Crouzel (La doctrine du caractère sacerdotal est-elle en contradiction avec la tradition occidentale d'avant le XII' siècle et avec la tradition orientale?, BLE 74:1973,

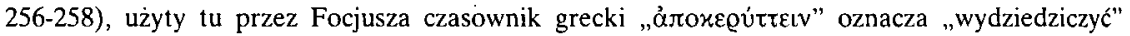
„ogłosić za wyjętego spod prawa, za wygnańca” "ogłosić zakaz" (Słownik grecko-polski, red. Z. Abramowiczówna, I, Warszawa 1958, 271-272) i wyraża depozycję z urzędu, nie stwierdza natomiast nieważności święceń, do wyrażenia której używano zazwyczaj przymiotnika „öxu@o૬" - „nieważny" „nie mający mocy prawnej” (tamże, s. 79), jak to miało miejsce w 16. kanonie Soboru Nicejskiego z $325 \mathrm{r}$, dotyczącym oceny prawnej święceń udzielonych przez obcego biskupa bez pozwolenia własnego. Decyzja Demetriusza mogła więc dotyczyć tylko zakazu wykonywania funkcji kaplańskich, por. M. Szram, Orygenes o kapłaństwie. Antologia tekstów, Olsztyn 1998, 12-13. P. Nautin uważa, że gdyby Demetrios miał na myśli orzeczenie nieważności święceń, byłoby to wyraźnym nadużyciem jego praw, zob. P. Nautin, Origène, I: Sa vie, son oeuvre, Paris 1977, 105 i 428.

71 Canones Apostolici 24, PL 67, 144: „Laicus semetipsum abscindens, annis tribus communione privetur, quia suae vitae insidiator extitit".

${ }^{72}$ Por. Constitutiones Apostolicae VIII 47; zob. Browe, dz. cyt., s. 29.

${ }^{73}$ Por. Concilium Arelatense can. 7, Mansi 7, 907: „Hi, qui se, carnali vitio repugnare nescientes, abscindunt, ad clerum pervenire non possunt".

${ }^{74}$ Por. Concilium Bracarense can. 21, Mansi 9, 852 B: „Si quis non per disciplinam religionis et abstinentiae, sed per abscissionem plasmati a Deo corporis, aestimans a se posse carnales concu- 
zakazów, zdarzały się również w okresie ponicejskim przypadki samookaleczenia się duchownych, głównie z powodu pobudek ascetycznych. Bazyli z Ancyry w poł. IV wieku (ok. 336-358) pisze:

„ci, którzy przewrotnie kastrują samych sicbie, dają przez ten czyn świadectwo

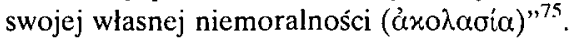

Zwraca też uwagę na konieczność powstrzymania licznych eunuchów, którzy zajmują eksponowane miejsca w Kościele. Pod koniec IV wieku Jan Chryzostom krytykuje kastrację jako bieżące nadużycie ${ }^{76}$ i nazywa je rodzajem morderstwa, które w duchu manichejskim niszczy dzieło Boskiego stworzenia ${ }^{77}$. $\mathrm{Z}$ różnych źródeł wiadomo, że za eunuchów byli uważani patriarchowie Konstantynopola: Macedoniusz (496-511), Germanus ( $† 733)$, Mctodiusz ( $†$ 846) i Ignacy $(\dagger 897)^{78}$. Nie mamy pewności, o jakiego rodzaju kastracje chodziło w tych przypadkach, przymusowe czy dobrowolne, ani $z$ jakich motywów je podejmowano.

D. Caner przytacza także szereg przykładów kastracji osób duchownych, podjętej z powodu uniknięcia podejrzeń $w$ związku $\mathrm{z}$ rozpowszechnioną praktyką ich życia wspólnego z agapetkami ${ }^{79}$. Np. św. Atanazy, Teodoret z Cyru i Sokrates Scholastyk wspominają o przypadku niejakiego Leoncjusza z Frygii, prezbitera $z$ Antiochii, który żył z agapetką (dnie całe spędzał z niewiastą) o imieniu Eustolium. Nie chcąc odseparować się od niej, wykastrował się. Jego biskup Eustacjusz złożył go z urzędu z tego powodu, ale cesarz Konstancjusz II (337-362) mianowal go samowolnie biskupem Antiochii w 344 roku. Teodoret uznał tę ordynację biskupią, dokonaną w 19 lat po wydaniu przez Sobór Nicejski kanonu zabraniającego udzielania święceń kastratom, za niekanoniczną $^{80}$. Caner jest zdania, że potępienie zarówno takich profilaktycznych, jak $i$ czysto ascetycznych kastracji wiązało się w Kościele nic tylko z rozpowszechnieniem się duchowej interpretacji słynnego fragmentu Ewangelii św. Mateu-

piscentias amputari, castraverit se, non eum admitti decernimus ad aliquod clericatus officium", zob. Muth, dz. cyt., k. 325-326.

${ }^{75}$ De virginitate 61, PG 30, 793 A.

76 Por. Commentarius in Galatos V 12, PG 61, 668.

${ }^{77}$ Por. Commentarius in Matthaeum 62, 3, PG 58,600, zob. tenże, Homiliae in I Epistulam ad Corinthios 31, 1, PG 61, 258; tenże, Homiliae in Epistulam ad Romanos 4, 3, PG 60, 420; Ambrosius, De viduis 13, 75, PL 16, 270-271; tenże, Hexaemeron 3, 9, CSEL 32/1, 146.

${ }^{78}$ Por. Nicephorus, HE XVI 26, PG 147, 168; Iosephus Genesius, Historia de rebus Constantinopolit. IV, PG 109, 1097; Ioannes Zonaras, Annales XVI 1, PG 135, 12.

${ }^{79}$ Por. The practice and prohibition of self-castration, art. cyt., s. 398-415; S. Longosz, Pisma przeciw synezaktom, VoxP 13-15 (1993-1995), z. 24-29, 337-365 oraz polski przeklad De singularitate clericorum, tamże, s. 367-453.

${ }^{80}$ Por. Athanasius, Apologia de vita sua 26, PG 25, 677; tenże, Historia arianorum ad monachos 28, PG 25, 725; Theodoretus, HE II 23, GCS 44, 152-155; Socrates Scholasticus, HE II 26, PG $67,265$. 
sza 19, 12, ale także z powodu nieskuteczności samej praktyki, która jeśli była tylko kastracją niepelną (typu ,spado"), nie gwarantowała wcale dwóch pożą-

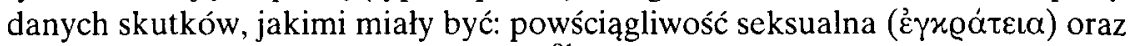
rozumna samokontrola ( $\sigma \omega \phi \varrho o \sigma u ́ v \eta)^{81}$.

Zachowane świadectwa występowania przypadków samokastracji wśród pierwszych chrześcijan utwierdzają zwolenników faktycznej kastracji Orygenesa w przekonaniu, że przypadek Aleksandryjczyka nie był niczym nadzwyczajnym, a wziąwszy pod uwagę brak w owym czasie wyraźnego ogólnokościelnego prawa przeciwnego kastracji oraz młody wiek i niedojrzałość Orygenesa, można go nawet usprawiedliwić. Oprócz powoływania się na relację Euzebiusza i na przykłady okaleczeń wśród chrześcijan w Kościele Wschodnim, badacze ci odwolują się również do własnych słów Orygenesa. Otóż we fragmencie napisanego po 244 r. Komentarza do Ewangelii św. Mateusza, Aleksandryjczyk interpretuje werset Mt 19, 10-12 (o trzech rodzajach eunuchów - bezżennych: z natury, uczynionych przez ludzi i podejmujących się dobrowolnie dla Królestwa niebieskiego), który miał się stać rzekomo podstawą jego czynu. Orygenes odrzuca wprawdzie zdecydowanie rozumienie dosłowne, cielesne i dopuszcza jedynie znaczenie alegoryczne tego fragmentu Pisma ${ }^{82}$, rozpoczyna jednak swój wywód następującym wprowadzeniem:

„My, którzyśmy kiedyś rozumieli Chrystusa, Slowo Boże, według ciała i litery, lecz teraz już nie rozumiemy go w ten sposób (por. 2 Kor 5,16 ), nie uznajemy za wlaściwą interpretacji tych, którzy rzekomo dla królestwa niebieskiego zadali sobie [...] niezdolność do małżeństwa. I nie traciłbym dłużej czasu na zbijanie poglądu tego, kto [...] niezdolność [...] chce pojmować cieleśnie, gdybym nie widział takich, co się na to odważyli i nie spotkal tych, którzy do takiego czynu potrafią skłonić co gorętszą dusz̨̨ wierzącą, lecz nie bardzo shuchającą rozumu"83.

Większość badaczy (H. Crouzel, S. Kalinkowski, D. Caner, P. Brown) dopatruje się w tych zdaniach odwołania się Orygenesa do własnego doświadczenia i przejawu żalu za czyn popełniony w młodzieńczej gorliwości. Są przekonani, że użyte nieco dalej przez Aleksandryjczyka stwierdzenie o ludziach,

${ }^{81}$ Por. Caner, art, cyt., s. 398.

82 Orygenes stwierdza, że uczynienie się niezdolnym do małżeństwa ze względu na Królestwo niebieskie polega na odcięciu pożądliwości od własnej duszy za pomocą słowa, por. Origenes,

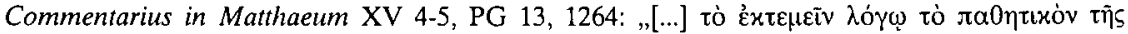

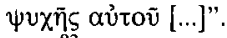

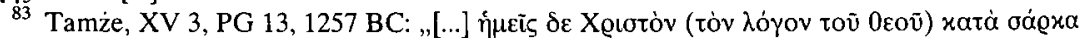

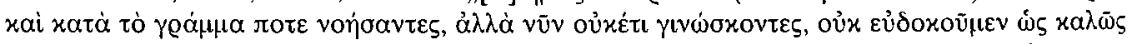

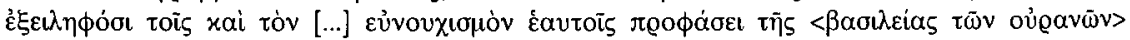

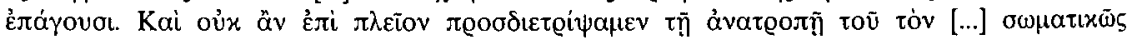

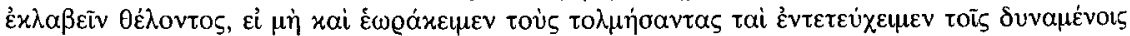

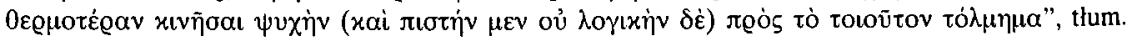
K. Augustyniak, ŹMT 10, 232. 
którzy „przez nieznajomość drogi prowadzącej do wstrzemięźliwości uwikłali się w tak niefortunne położenie" oraz szczegółowe uwagi autora o przykrościach psychicznych (zaburzenia wyobraźni) i fizycznych (brak zarostu na twarzy, ociężałość i zawroty głowy) będących następstwami kastracji również wynikają z własnych doświadczeń i potwierdzają czyn Orygenesa ${ }^{84}$.

\section{ARGUMENTACJA PODWAŻAJĄCA AUTENTYCZNOSĆ SAMOKASTRACJI ORYGENESA}

Przedstawiona powyżej argumentacja za autentycznością samokastracyjnego czynu Orygenesa nie jest przekonująca dla wszystkich badaczy ${ }^{85}$. W przytoczonym materiale źródłowym znajdują się bowiem stwierdzenia, które nie są jednoznaczne i pewne. Również kontekst historyczny i teologiczny epoki pozwala na postawienie pewnych znaków zapytania. W XIX wieku do relacji Euzebiusza o czynie Aleksandryjczyka odnieśli się sceptycznie dwaj Niemcy: K.F. Schnitzer ${ }^{86}$ i F. Böhringer ${ }^{87}$, na początku XX wieku ich opinię podzielili A. Harnack i E. Klostermann, a pod koniec ubiegłego stulecia autokastrację Aleksandryjczyka podali w wątpliwość H. Chadwick ${ }^{88}$ i I. Dechow ${ }^{89}$. Przedstawię więc obecnie „drugą stronę medalu”, czyli argumentację przeciwną, przytaczaną przez wspomnianych historyków i patrologów, a także kwestie, które budzą moje osobiste wątpliwości, jakie pojawiły się po analizie przytoczonych wyżej i innych, nie wymienionych dotąd tekstów źródłowych.

Zastanawiający jest fakt, że relacja Euzebiusza jest jedynym wyraźnym świadectwem wczesnochrześcijańskim, w którym „expressis verbis” i bez zastrzeżeń mówi się o interesującym nas czynie Orygenesa ${ }^{90}$. Do takiego „testimonium unius testis" należy pođchodzić $\mathrm{z}$ dużą ostrożnością, jak sugeruje nawet H. Crouzel, skłaniający się ku uznaniu kastracji Aleksandryjczyka za fakt. Trzeba też pamiętać, że relacja Euzebiusza jest ponad 100 lat późniejsza od rzekomego czynu Orygenesa. Nie wiadomo, skąd Euzebiusz zaczerpnął informację o czynie Orygenesa. Czy nie powstała ona, jak sądzi H. Chadwick, na podstawie

84 Por. tamże, s. 233.

85 Por. R. Williams, Origenes/Origenismus, TRE XXV 398.

${ }^{86}$ Por. Origenes über die Grundlehren der Glaubenswissenschaft, Stuttgart 1835, 33-40.

${ }^{87}$ Por. Die Kirche Christi und ihre Zeugen, Zürich 1842, 111.

${ }^{88}$ Por. Myśl wczesnochrześcijańska a tradycja klasyczna, tłum. P. Siejkowski, Poznań 2000, 74.

${ }^{89}$ Por. Dogma and Mysticism in Early Christianity. Epiphanius of Cyprus and the Legacy of Origen, Macon 1988, 133-135.

90 Zdanie z 84. listu Hieronima wydaje się być streszczeniem relacji Euzebiusza, zob. Hieronymus, Epistulae 84, 8, CSEL 55, 130: „[...] voluptates in tantum fugit, ut zelo Dei, sed non secundum scientiam ferro truncaret genitalia [...]", thum. J. Czuj (Św. Hieronim, Listy, II, Warszawa 1953) s. 250: „rozkoszy unikał do tego stopnia, że z gorliwości Bożej, ale nie według tego, co wiedzieć należy ( $R z 10,2)$, sam się otrzebił żelazem". 
ustnej tradycji i plotek podczas pierwszej fazy sporów orygenesowskich, aby i w ten sposób pognębić teologa podejrzewanego o nieortodoksję? ${ }^{91}$.

Mamy prawo nie ufać do końca Euzebiuszowi, gdyż wiarygodność wielu fragmentów jego Historii jest kwestionowana przez współczesnych badaczy. Klasycznym przykladem jest kwestia rzekomego istnienia „od niepamiętnych czasów”, jak twierdzi Euzebiusz, oficjalnej szkoły katechetycznej, w której nauczycielami mieli być kolejno Pantajnos, Klemens Aleksandryjski i Orygenes $^{92}$. Od czasu badań przeprowadzonych na początku ubiegłego stulecia przez znanych patrologów francuskich R. Cadiou ${ }^{93}$ i G. Bardy'ego ${ }^{94}$ wiadomo, ze właściwą szkołę katechetyczno-teologiczną założyl dopiero Orygenes w 215 r., natomiast tzw. szkoła Pantajnosa miała najprawdopodobniej charakter filozoficzny i nie była jeszcze oficjalną instytucją kościelną ${ }^{95}$. Wątpliwości co do pełnej wiarygodności historycznej dzieła Euzebiusza wyraża również znany francuski badacz Orygenesa - P. Nautin, chociaż akurat co do jego przekazu o autokastracji Orygenesa jest skłonny dawać wiarę historykowi z Cezarei ${ }^{96}$. Generalnie Nautin uważa Euzebiusza za historyka uczciwego, ale zarzuca mu niejednokrotnie nadinterpretację wydarzeń, brak zmysłu historycznego,

91 Tak np. interpretuje powstanie tradycji o kastracji Orygenesa Chadwick (Myśl wczesnochrześcijańska, s. 74): „Kiedy Euzebiusz opiera się na dokumentach z czasu wydarzeń, które opisuje, jego autorytet jest niepodważalny. Kiedy natomiast polega tylko na pogloskach i tradycji ustnej, jego autorytet jest nie większy niż najbardziej nawet wiarygodnego plotkarza. [...] Opowieść [o kastracji Orygenesa] jednak nie należy do tych, które Euzebiusz przytacza na podstawie dostępnych mu dokumentów. W tym wypadku polega on na niepisanej tradycji. [...]. Możliwe, że [przekaz] powstał na drodze złośliwej plotki. Pewne jest przynajmniej to, że tak skrajne wyrzeczenie siebie w życiu Orygenesa, młodego nauczyciela, wywołało wiele szumu i zazdrosnych komentarzy, podsycanych jeszcze bardziej przez stanowczość jego jawnej krytyki kompromisów ze światem, zawieranych przez kler i świeckich".

${ }_{92}$ Euzebiusz najpierw pisze, że Klemens byl następcą Pantajnosa w aleksandryjskiej szkole katechetycznej aż do prześladowania chrześcijan za Septymiusza Sewera w 202 r., a jego uczniem i następcą miał być z kolei Orygenes, zob. HE VI 6, SCh 41, 94. Sam sobie jednak przeczy, gdy w tej samej księdze swej Historii, opowiadając o Orygenesie wyraźnie podaje, ze wprowadzał go w arkana wiary chrześcijańskiej rodzony ojciec.

93 Por. La jeunesse d'Origène. Histoire d'Ecole d'Aléxandrie au debut du III siècle, Paris 1936.

94 Por. Aux origines de l'Ecole d'Aléxandrie, RSR 27 (1937) 65-90.

95 H. Pietras jest przekonany, że Orygenes nie był formalnie uczniem Klemensa, nigdy zresztą w swych pismach nie powołuje się imiennie na Klemensa, chociaż jest wyraźnym kontynuatorem jego myśli. Wspólcześnie panuje również przekonanie, że szkoła Klemensa, podobnie jak wcześniej Pantajnosa, wbrew temu co pisze Euzebiusz, nie miała katechetycznego charakteru. Była to szkoła prywatna, na wzór innych szkół filozoficznych, gdzie wykładał on filozofię, jako przygotowanie do chrześcijaństwa, a przede wszystkim ewangelię jako zwieńczenie całej filozofii, por. H. Pietras, Poczq̨itki teologii Kościoła, Kraków 2000, 122-123.

${ }_{96}$ Nautin uważa, że informację o kastracji Orygenesa mógł Euzebiusz zaczerpnąć z listu biskupów palestyńskich Aleksandra i Teoktysta wystosowanego rzekomo do papieża Poncjana w obronie przed biskupem Demetriuszem ich decyzji udzielenia święceń Aleksandryjczykowi, jednak istnienie takiego listu jest tylko hipotezą, a treść - domniemaną rekonstrukcją, por. P. Nautin, Lettres et écrivains chrétiens des II et III siècles, Paris 1961, 124-126. 
a przede wszystkim snucie wątpliwych analogii i mieszanie faktów. Np. Euzebiusz, wiedząc, że Orygenes miał mistrza w zakresie filozofii o imieniu Ammoniusz, identyfikuje go bezkrytycznie $\mathrm{z}$ autorem chrześcijańskiego dziełka o zgodności Ewangelii o tym samym imieniu, nie wziąwszy pod uwagę, żc imię Ammoniusz występowało w owych czasach bardzo często i homonimia w tym przypadku nie musi być wcale dowodem identyczności obu postaci ${ }^{97}$.

Oprócz tego, że relacja Euzebiusza o autokastracji Orygenesa nie jest oparta na pewnych przekazach ani potwierdzona przez inne, wcześniejsze świadectwa, jest jeszcze dziwnie niespójna. Zdziwienie może budzić nagła zmiana stanowiska Demetriosa, który najpierw zachwycał się czynem Orygenesa, a kilkanaście lat później uważał go za wysoce naganny. Ponadto niezrozumiałe jest określenie motywu Orygenesowego czynu, zawierające wewnętrzną sprzeczność. Otóż Euzebiusz pisze, że Aleksandryjczyk „,pragnął nicwiernym odebrać wszelki powód do brzydkiego posądzania, jako że w młodym wieku głosił słowo Boże nie tylko mężczyznom, ale także niewiastom". Z powyższego sformułowania wynika, że czyn Orygenesa, aby spełnić swoje zadanie, musial być ujawniony i nagłośniony. W następnym zdaniu jednak Euzebiusz mówi coś zupełnie innego: „[Orygenes] postanowił więc wykonać rzeczywiście slowa Zbawiciela, a starał się tylko o to, by rzecz tę ukryć przed wielką liczbą uczniów swoich" ${ }^{98}$.

Zwolennicy faktycznej autokastracji Orygenesa (P. Nautin, H. Crouzel) argumentują, że Euzebiusz jako zwolennik Aleksadryjczyka z pewnością przemilczałby kompromitujący $z$ punktu widzenia znanego mu prawodawstwa nicejskiego czyn Orygenesa, gdyby nie miał pewnych dowodów co do jego autentyczności. Przeciwnego zdania jest współczesny badacz amerykański I. Dechow, który uważa, że wzmianka o autokastracji miała właśnie służyć przedstawieniu Orygenesa $\mathrm{w}$ korzystnym świetle. Zdaniem Dechowa, przekaz o rzekomym pozbawieniu się przez Orygenesa męskości miał w opisie konfliktu wokół święceń Aleksandryjczyka zastąpić o wiele poważniejsze zarzuty dotyczące nieortodoksyjności jego nauki, o których Euzebiusz w ogóle nie wspomina. Koronnym argumentem Dechowa przeciw autentyczności relacji Euzebiusza jest sceptycyzm Epifaniusza z Salaminy, który mimo swej postawy walczącego antyorygenisty, nazywa ustne relacje o rzekomym czynie Oryge-

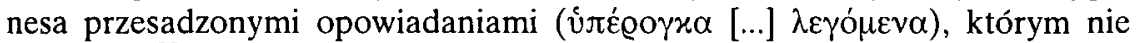
daje wiary ${ }^{99}$. Epifaniusz, nawiązując do owych blizej nie znanych przekazów

${ }^{97}$ Por. Eusebius, HE VI 19, SCh 41, 119, P. Nautin, Origène, I. Sa vie, son oeuvre, Paris 1977, 25, H. Dörrie, Ammonios der Lehrer Plotins „Hermes” 83 (1955) 439-477; F.M. Schroeder, Ammonios Sakkas, ANRW 36, 1, Berlin - New York 1986, 493-526.

98 HE VI 8, 2, SCh 41, 93, POK 3, 260.

${ }^{99}$ Por. Epiphanius, Panarion LXIV 3, 13, GCS 31, 409; zob. I.F. Dechow, Dogma and Mysticism in Early Christianity. Epiphanius of Cyprus and the Legacy of Origen, Patristic Monograph Series 13, Macon 1988, 133-135. 
ustnych, porusza przede wszystkim kwestię sposobu, w jaki Orygenes mógł okaleczyć swoje ciało. Jak pamiętamy, Euzebiusz nie sprecyzowal, jak konkretnic Aleksandryjczyk wypełnil zinterpretowane dosłownie słowa z Mt 19, 12. Hieronim, który powtarza dokładnie relację Euzebiusza, precyzuje, że Orygenes „ferro trunacaret genitalia”, ale być możc jest to domysł lub spontaniczne stwierdzenic, ponieważ taka praktyka byla najbardziej rozpowszechniona i latwa do wyobrażenia ${ }^{100}$. Epifaniusz natomiast wymienia dwie zupełnie inne opinie dotyczącc technicznej strony ewentualnego Orygenesowego samookaleczenia. Według jednej Aleksandryjczyk uszkodził (przerwał, oderwał) jakiś nerw, co spowodowało wolność od podniet wywolywanych przez cielesne bodźce oraz odbierało możliwość doznawania cielesnej przyjemności; według drugiej - wynalazł jakiś narkotyczny (ziołowy) lek, który po posmarowaniu genitaliów spowodował ich uschnięcie ${ }^{101}$. Być może chodziło o zastosowanic cykuty; lekarze starożytni podawali bowiem receptę na bezkrwawe pozbawienie się męskości przez oblożenie jąder utartym korzeniem cykuty rozpuszczonym w occie, tzw. "thlasia" "102 . Nota bene, sam Orygenes pisze w Contra Celsum o pewnym kapłanie bogini Demeter z Aten, który posmarował cykutą genitalia, aby uwiarygodnić swoją czystość i kierować religijnymi nabożeństwami ateńskimi, dodając jednak od razu zdecydowaną krytykę takiego procederu:

„[Chrześcijanie] nie potrzebują cykuty, aby w czystości służyć Bogu; Słowo Boże jest dla nich cykutą, ono powoduje, że wyrzucają z duszy pożądliwości i czczą Boga modlitwami" 103 .

Żadna $z$ dwóch relacji ustnych, przywołanych przez Epifaniusza, nie wspomina o pełnej kastracji Orygenesa ani o użyciu noża, a nawet te, które biskup Salaminy przytacza, nazywa wyolbrzymionymi. Wydaje się więc, że kluczowe źródła historyczne, jakimi są dla naszej kwestii Historia Kościelna Euzebiusza

${ }^{100}$ Zob. przypis nr 90; P. Brown (dz. cyt., s. 168) i A. Rousselle (dz. cyt., s. 158-164) uważają, że kastracja była rutynową operacją w tamtych czasach i Orygenes dokonal jej dyskretnie u lekarza.

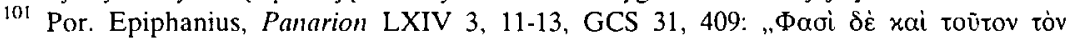

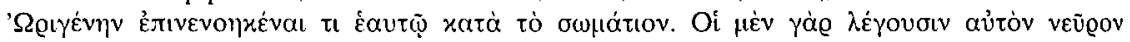

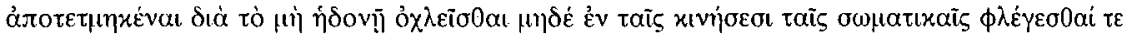

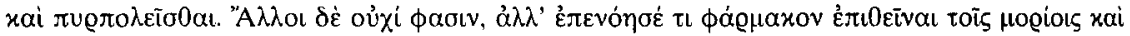

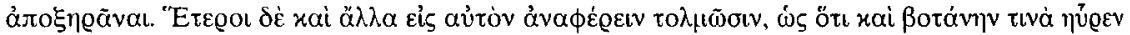

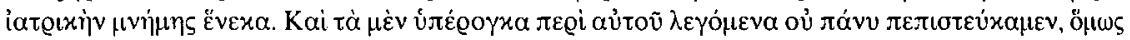

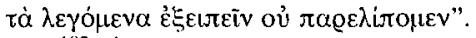

102 Źródła antyczne wspominają jeszcze o innych środkach roślinnych na okładanie jąder w celu ich wysuszenia: cebulkach hiacyntowych w winie i przecierze z fasoli, zob. Plinius. Historia naturalis XXI 170. Innym sposobem kastracji stosowanym w Cesarstwie Rzymskim oprócz obcięcia jąder mieczem $i$,thlasii” była „thlibia”, czyli zmiażdżenie jąder przez ich ściśnięcie, por. D. Dalla, L'incapacità sessuale in diritto romano, Milano 1978, 48.

103 Contra Celsum VII 48, SCh 150, 128, thum. S. Kalinkowski: Orygenes, Przeciwko Celsusowi, Warszawa 1986, 369. O podobnych przypadkach wspominają również Hipolit (Philosophoumena V 8, PG 16, 3150) i Hieronim (Adversus Ioviniamum I 49, PL 23, 282). 
i Panarion Epifaniusza, pozwalają z dużą dozą prawdopodobieństwa przypuszczać, że samookaleczenie Orygenesa, nawet jeżeli było faktem, nie miało charakteru całkowitej kastracji.

Najtrudniej jednak pogodzić autokastrację Orygenesa z jego własną, wyłącznie duchową, interpretacją zdania Mt 19, 12, zawartą w Komentarzu do Ewangelii św. Mateusza. Eksponuje ona wstrzemięźliwość i bezżeństwo jako istotę właściwie pojętego eunuchizmu. Zwolennicy uznania kastracji Orygenesa za fakt dopatrują się w takiej egzegezie mimo wszystko autobiograficznych odniesień. Orygenes rozpoczyna bowiem duchową interpretację tekstu Pawłowego o niezdolności do małżeństwa od zdania, które może zabrzmieć bardzo autobiograficznie:

„My, którzyśmy kiedyś rozumieli Chrystusa, Słowo Boże, według ciała i według litery, lecz teraz już nie rozumiemy Go w ten sposób (por. 2Kor 5, 16), nie uznajemy za właściwą interpretacji tych, którzy rzekomo dla królestwa niebieskiego zadali sobie [...] niezdolność do malżeństwa"104.

Jeżeli odnieślibyśmy tekst do samego Orygenesa, sugerowałby on, że Aleksandryjczyk początkowo interpretował Pismo św. dosłownie, a dopiero z czasem przekonał się do egzegezy alegorycznej. Tymczasem zachowane pisma egzegetyczne jego autorstwa nie wykazują żadnej ewolucji poglądów co do stosowanej metody egzegezy i nie wskazują jakoby kiedykolwiek Orygenes miał być zwolennikiem literalnej lektury Biblii. Przeciwnie, to właśnie z wczesnego okresu twórczości, gdy przebywał w Aleksandrii (według P. Nautina - lata 229-232), pochodzą obfitujące w alegorie Komentarze do Księgi Rodzaju i Ewangelii św. Jana, a przede wszystkim traktat $O$ zasadach, w którego IV księdze została wyłożona właśnie metoda egzegezy alegorycznej, w pełni już uksztaltowana i usystematyzowana. Nie możemy oczywiście wykluczyć, że 20-letni Orygenes, który jeszcze nie pisał dzieł egzegetycznych, mógł w młodzieńczej gorliwości ascetycznej rozumieć pewne teksty biblijne dosłownie. Jednak zachowane pisma, choć nie sięgają tak młodzieńczego wieku autora, ukazują go zawsze jako człowieka w pełni przekonanego do alegorycznej egzegezy trudnych i skrajnych tekstów Pisma św., odczuwającego ją duchowo i nie dopuszczającego innej możliwości wyjaśniania Biblii. Skoro zatem wspomnianego zdania z Komentarza do Ewangelii św. Mateusza nie potwierdzają inne dane, nie możemy uznać go za wystarczający dowód, że Orygenes w młodości był literalistą w interpretacji Pisma świętego. Być może użyta przez Aleksandryjczyka 1. osoba liczby mnogiej nie odnosi się do samego autora Komentarza, ale obejmuje grono odbiorców, do których się zwraca. Było wśród nich z pewnością wielu takich, którzy właśnie pod wpływem egzegezy alegorycznej Orygenesa zaczęli rozumieć Pismo św. nie według ciała i litery, ale duchowo.

${ }^{104}$ Commentarius in Matthaeum XV 3, PG 13, 1257 B, ŹMT 10, 232. 
Autor Komentarza wielokrotnie w swoim dziele używa 1. osoby liczby mnogiej, ogarnia nią w kaznodziejskim stylu także czytelników, gdy pisze np.: ,[...] my, którzy jesteśmy duchowi, słowa Boże przyjmujemy na sposób duchowy. [... będziemy] mogli lepiej wtedy żyć, jeśli pojmiemy prawdziwą myśl rozpatrywanych treści" ${ }^{105}$. Ponadto należy zwrócić uwagę na fakt, że słowa ,rozumieliśmy Słowo Boże według ciała i według litery, lecz teraz nie rozumiemy go już w ten sposób", są lekko zmienionym cytatem z 2 Kor 5, 16 św. Pawla i mogą w wypowiedzi Orygenesa pełnić przede wszystkim funkcję retoryczną.

W omawianym fragmencie Komentarza do Ewangelii sw. Mateusza Orygenes pisze, ze widział ludzi, którzy „z bojaźni przed Bogiem, lecz z nieznajomością rzeczy" dopuścili się samokastracji, interpretując dosłownie tekst Mt 19, 12 oraz takich, którzy naklaniają do tego czynu. Dla zwolenników uznania autokastracji Orygenesa za fakt stwierdzenie to ma wydźwięk wyraźnie osobisty. Uważają, że Aleksandryjczyk, pisząc u schyłku życia swój Komentarz, żałował czynu popełnionego w młodości i pisząc o rzekomych innych osobach, miał na myśli samego siebie. Jest to jednak tylko domysł. Można przecież równie dobrze przyjąć, że Orygenes myślał istotnie o innych ludziach, a nie o sobie, a ów fragment mógł zostać odniesiony dopiero przez potomnych do samego autora w ferworze sporów dotyczących jego osoby, kiedy to wrogowie znieksztalcali jego naukę i przypisywali mu to, co najgorsze. Może więc Orygenes nie myśli tu o sobie, a przekonanie o jego autokastracji powstało właśnie pod wpływem tej wypowiedzi, interpretowanej błędnie jako osobiste zwierzenie zakamuflowane dla niepoznaki w stwierdzeniu o jakichś trzecich osobach.

Należy wreszcie zwrócić uwagę na najważniejszą kwestię, która może wywoływać wątpliwości co do fizycznej autokastracji Orygenesa, a której przeoczenie mogło dać początek posądzeniom go o ten czyn. Chodzi mianowicie o znaczenie słowa „enobcoj”, które oznaczalo nie tylko tego, kto fizycznie pozbawił się męskości. W Piśmie św. hebrajski termin „saris” i grecki „દưvoúxo૬" (dosłownie „stróż łoża”) mógł oznaczać mężczyznę pozbawionego męskości (zarządca dóbr królowej Kandaki był kastratem - Dz 8, 27. 34. 36. 38) ale też, w sensie przenośnym, dowódcę straży lub wysokiego urzędnika (Putyfar był żonaty $-\mathrm{Rdz} 39,1.7)^{106}$. Teksty wskazujące na duchowe znaczenie terminu „£ủvoúxo $\varsigma^{\prime}$ mnożą się od końca II wieku ${ }^{107}$, najprawdopodobniej jako reakcja na dosłowne rozumienie tego slowa w słynnym fragmencie Mt 19, 12, który nie precyzował jednoznacznie o jaki rodzaj eunuchizmu chodziło Chrystusowi. W II wieku apologeta Atenagoras charakteryzuje chrześcijan jako

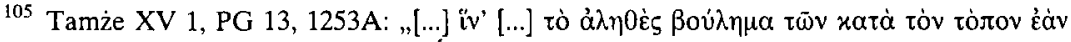

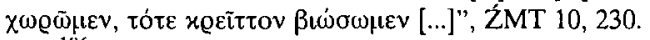

106 Por. X. Leon-Dufour, Stownik Nowego Testamentu, tłum. K. Romaniuk, Poznań 1986, 253-254.

${ }^{107}$ Por. Muth, dz. cyt., k. 325. 


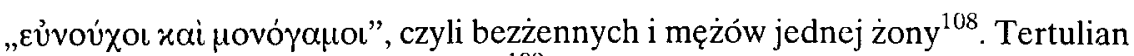
samego Chrystusa nazywa „spado" 109 . Kontekst obu wypowiedzi wskazuje, że chodzi o duchowe pojmowanie terminów „Ev̉voúxos" i „spado”.

Zachowane teksty pochodzące $z$ chrześcijańskiego środowiska aleksandryj-

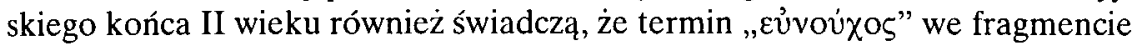
Mt 19, 12 rozumiano tam przenośnie. Główny filozof i teolog działający przed Orygenesem w Aleksandrii, Klemens, zdecydowanie opowiada się za ducho-

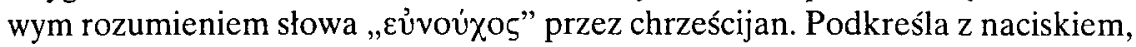
że stałość i czystość duszy jest wewnętrzną cnotą, której nie trzeba podkreślać zewnętrznymi znakami. Zwraca również uwagę, że bezżenność i czystość człowieka, zwanego eunuchem, powinny być jego wolnym wyborem, nie mogą być natomiast wymuszane fizycznym okaleczeniem ${ }^{110}$. Tym samym Klemens przeciwstawia się zdecydowanie dosłownej interpretacji innego tekstu z Ewangelii Mateusza 5, 27-30 o odcięciu i odrzuceniu gorszącej części ciala. Nawiązując do poglądów głoszonych przez zwolenników gnostyka Bazylidesa, Klemens nazywa dobrowolnymi „,eunuchami” tych bezżennych, którzy nie zawierają małżeństwa albo dla Królestwa niebieskiego albo ze względu na trudne okoliczności życia małżeńskiego, to jest $z$ obawy przed trudem zdobywania środków utrzymania $^{111}$. Nieco dalej, komentując zdanie z Pwt 23, 2 - ,żaden eunuch nie wstąpi do spoleczności Boga”, podaje Klemens jeszcze inne przenośne rozumienie tego terminu, nie związane ze wstrzemięźliwością seksualną. Eunuch oznacza tu, jego zdaniem „każdego, kto w postępowaniu i w słowie jest bez-

${ }^{108}$ Por. Supplicatio pro Christianis 34, 3, SCh 379, 200; Augustinus, De virginitate 25, PL 40, 409.

109 Por. De monogamia 3, CCL 2, 1230-1231: „[... ] ipso Domino spadonibus aperiente regna caelorum, ut et ipso spadone [...]"; tenże, De resurrectione mortuonum 61, CCL 2, 1010.

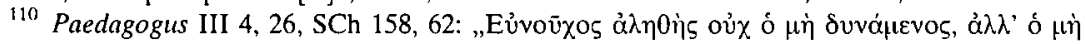

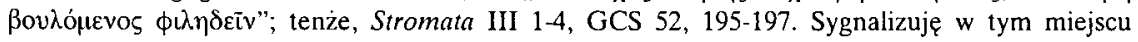
istnienie nowego opracowania, do którego nie zdołałem dotrzeć: M. Horstmanshoff, Who is the true eunuch? Medical and religious ideas about eunuchs and castration in the works of Clement of Alexandria, w: From Athens to Jerusalem, red. M. Horstmanshoff - S. Kottek, Rotterdam 2000, 101-117.

111 Stromata III 1, GCS 52, 195. Mimo, ze Klemens nie podziela negatywnego stosunku Bazylidesa do małżeństwa, przyjmuje jako dopuszczalną jego egzegezę fragmentu Mt 19,12 : „Zwolennicy [...] Bazylidesa [chodzi o Izydora, syna Bazylidesa, autora dzieła Etyka] wyjaśniają te słowa [Mateusza] mniej więcej tak: Niektórzy mają fizyczną niechęć do kobiety od urodzenia. Kto stosuje tę naturalną wstrzemięźliwość, czyni dobrze, nie żeniąc się. To są - ich zdaniem - ci eunuchowie od urodzenia. A znowu owymi eunuchami z konieczności [nie - wg O. Stachlina] są tamci pompatyczni asceci, którzy ze względu na urzekającą perspektywę dobrej sławy utrzymują swe żądze na wodzy, lecz kastraci na skutek nieszczęśliwego wypadku. A więc owi niezdolni do małżeństwa na skutek konieczności nie są tymi niezdatnymi do małżeństwa na skutek własnego przekonania. Którzy zaś ze względu na Królestwo niebieskie sami wyrzekli się małżeństwa, czynią to postanowienie, jak oni mówią, ze względu na trudne okoliczności życia małżeńskiego, to jest z obawy przed trudem zdobywania środków utrzymania" (tłum. J. Niemirska-Pliszczyńska, Kobierce 1, s. 229). 
płodny i bezowocny. [...] nie tego, który przymusowo został pozbawiony swych organów płodzenia, ani też bezżennego, ale tego, kto jest niezdolny do płodze-

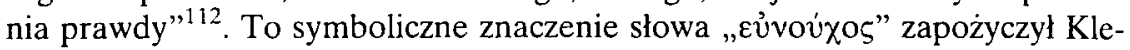
mens zapewne od Filona Aleksandryjskiego, który uważał, że eunuch może

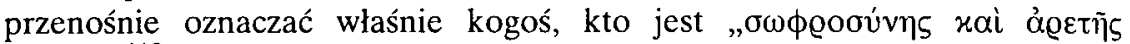
ă ovo $" 113$. Wychowany w Aleksandrii i znający z pewnością od młodości nauczanie Klemensa Orygenes nie mógł nie zetknąć się z tą duchową egzegezą, której tak zażartym zwolennikiem i obrońcą byl sam w późniejszym życiu. Identyczny tok myślenia, jak Klemens, prezentuje Orygenes w Komentarzu do Ewangelii św. Mateusza:

„eunuchami w sensie alegorycznym można nazwać tych, co wstrzymują się od przyjemności zmyslowych i nie oddają się rozwiązłości, nieczystości i podobnym namiętnościom (por. 2Kor 12, 21)”"114, ale „z pomocą słowa odcinają pożądliwość swej duszy"115; ,,jeśli trzeba sięgnąć [...] do opowiadań zawartych w Pismach, przeprowadzając [...] ich duchową interpretację powiemy, że są pewni eunuchowie faraona, [czyli ludzie] nie rodzący żadnego dobra (por. Rdz 40) [...] i są ludzie Boga [niezdolni do małżeństwa, czyli] nie rodzący żadnego zła (por. 2Ezd 1, 11; 2, 1.6 LXX; Iz 39, 7; 56, 3.5)"116.

Również w Homiliach do Księgi Kapłańskiej Aleksandryjczyk zwraca uwagę, że istotą otrzebienia się dla Królestwa Niebieskiego jest wstrzemięźliwośćl ${ }^{11}$. Interpretację dosłowną Orygenes nazywa fáłszywą, literą która zabija, obelgą dla słowa Bożego i zaprzeczeniem słów Pwt 23, 1 oraz przestrzega przed ludźmi, którzy ją przyjęli.

Cała późniejsza zachowana egzegetyczna tradycja pisana pierwotnego Kościoła opowiada się za duchowym rozumieniem terminu „દv̉voúxos" w odniesieniu do trzeciej grupy dobrowolnych bezżennych ze względu na Królestwo Niebieskie w tekście Mt $19,12^{118}$. O duchowych eunuchach w odniesieniu do

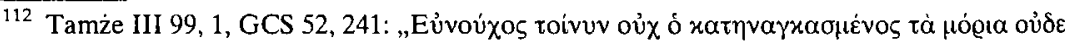

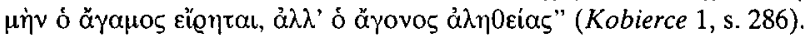

113 Por. De Iosepho 153; De ebrietate 211-224; De somniis II 184; Legum allegoriae III 236-245; Quaestiones in Genesim II 65, 70, 77.

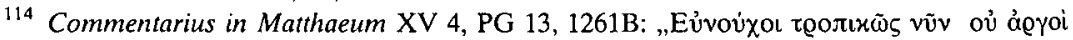

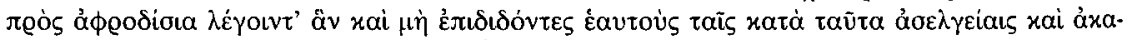

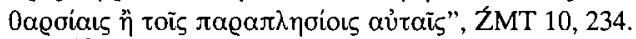

115 Tamże XV 4, PG 13, 1264A.

116 Tamże, 15, 5, PG 13 1264BC, ŹMT 10, 235.

117 Por. Origenes, Homiliae in Leviticum 10, 2, SCh 287, 140: „Quomodo quis se ipsum castrat propter regnum caelorum [...] nisi abstinentia utatur ministra ?". Co ciekawe, Orygenes odnosi duchowe rozumienie terminu „Eủvoúxoร" do wszystkich trzech grup eunuchów, wymienionych w tekście Mt 19, 12 - z urodzenia, uczynionych przez ludzi i dobrowolnych, krytykując nie tylko tych chrześcijan, którzy ostatnią grupę rozumieją dosłownie, ale także tych, którzy interpretując ją duchowo, przypisują dosłowne, cielesne znaczenie dwóm pierwszym.

118 Por. W. Bauer, Matth. 19, 12 und die alten Christen, w: Neutestamentliche Studien, Leipzig 1914, 235-244. 
wspomnianego zdania z Ewangelii św. Mateusza wspomina wielu pisarzy wczesnochrześcijańskich, jak np. Grzegorz z Nazjanzu ${ }^{19}$, Jan Chryzostom ${ }^{120}$, Hieronim $^{121}$ czy Bazyli $z$ Ancyry ${ }^{122}$. U autorów opisujących życie mnichów spotykamy kilkakrotnie topos zakonnika, doznającego w nocnej wizji duchowej kastracji przez anioła. Można go wprawdzie rozumieć, jako próbę duchowego uzasadnienia rzeczywistej kastracji, ale miał on chyba na celu obrazowe ukazanie istoty właściwie pojętego eunuchizmu duchowego, w czasach, gdy kastracje mnichów ze względów ascetycznych byly w Kościele zdecydowanie piętnowane $^{123}$. Nie ma natomiast, jak twierdzi D. Caner, zachowanych na piśmie interpretacji fragmentu Mt 19, 12 w duchu dosłownym, są tylko krytyczne wzmianki o niektórych ludziach, którzy w ten sposób zrozumieli ów fragment $z$ radykalnych pobudek ascetycznych ${ }^{124}$.

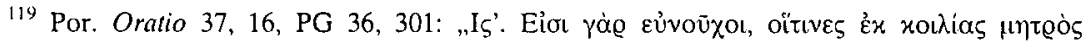

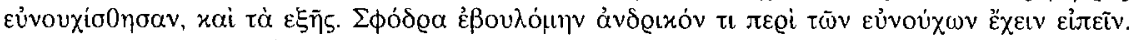

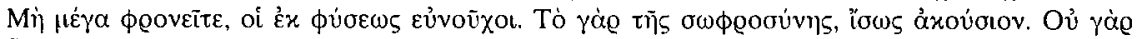

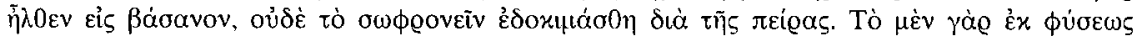

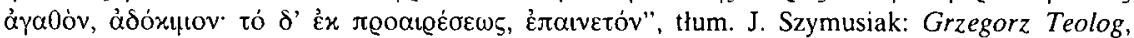
Poznań 1965, 375-376. Grzegorz interpretuje alegorycznie wszystkie trzy grupy eunuchów z tekstu Mt 19, 12 .

${ }^{120}$ Por. Commentarilus ad Galatos V 12, PG 61, 668-669; Homiliae in Matthaeum 17, 3, PG 58, 257-259.

121 Por. Commmentarius in Evangelium Matthaei III 19, SCh 259, 72-74. Hieronim podaje dwie alternatywne interpretacje Mt 19, 12: według jednej dwa pierwsze rodzaje eunuchizmu są cielesne, a trzeci - duchowy; według drugiej - wszystkie trzy należy interpretować duchowo. Nadrzędnym przesłaniem tekstu jest, według niego, zachęta do dobrowolnego, a nie przymusowego przyjęcia postawy dziewictwa i czystości: ,triplex genus genus est eunuchorum, duorum carnalium et tertii spiritalis. Alii sunt qui de matris utero sic nascuntur, alii vel quos captivitas facit vel deliciae matronales. Tertii sunt qui se ipsos castraverunt propter regnum caelorum et qui cum possent esse viri, propter Christum eunuchi fiunt. Istis promittitur praemium, superioribus autem quibus castimoniae necessitas non voluntas est, nihil omnino debetur. Possumus et aliter dicere: Eunuchi sunt ex matris utero qui frigidioris naturae sunt nec libidinem adpetentes, et alii qui ab hominibus fiunt quos aut philosophi faciunt aut propter idolorum cultum emolliuntur in feminas, vel persuasione heretica simulant castitatem ut mentiantur religionis veritatem. Sed nullus eorum consequitur nisi qui se propter Christum castraverit. Unde infert: Qui potest capere capiat, ut unusquisque consideret vires suas utrum possit virginalia et pudicitiae implere praecepta".

122 Por. De virginitate 60, PG 30, 792.

123 Por. Ioannes Cassianus, Collationes Patrum 7, 2, SCh 42, 244-246 (abba Serenus); Palladius, Historia Lausiaca 35, PG 34, 1097-1098 (asceta Eliasz z mieszanego klasztoru w Atribis w południowym krańcu Delty Nilu); Gregorius Magnus, Dialogi de vita et miraculis Patrum Italicorum 1, 4, SCh 260, 38 (Ekwicjusz, opat w prowincji Walerii). Nil z Ancyry radził jednemu $\mathrm{z}$ adresatów swoich listów - diakonowi Kyriakosowi, aby zamiast się fizycznie kastrować, prosił Boga o duchowa kastrację, zob. Epistulae I 323, PG 79, 200A; P. Boulhol - I. Cochelin, La rehabilitation de l'eunuque dans l'hagiographie antique (4/6 s.), w: Memoriam sanctorum venerantes. Festschrift V. Saxer, Città del Vaticano 1992, 49-76.

124 Por. Browe, dz. cyt., s. 30-31; W. Bauer, Matth. 19, 12 und die alten Christen, w: Neutestamentliche Studien, Leipzig 1914, 235-244. 
Orygenes, jak się wydajc, musiał być oswojony od młodych lat nie tylko

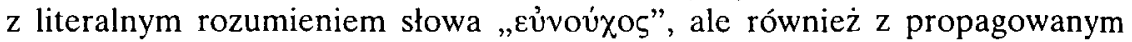
przez Klemensa jego znaczeniem duchowym i trudno uwierzyć, by mógł pozostawać na nie obojętnym. Skoro jednak „,ủvoúxos" oznaczał w potocznym rozumieniu zarówno fizycznego kastrata, jak i człowieka bezżennego, czy nie mogło stać się tak, że do Orygenesa jako ascety i człowieka żyjącego w czystości, zaczęto później odnosić ów termin również w pierwszym - dosłownym znaczeniu? W ten sposób kwestię jego rzekomej kastracji można byłoby wytłumaczyć nieporozumieniem terminologicznym. Oczywiście, jest to tylko oparta na przypuszczeniach hipoteza.

Zastanawiająca jest jeszcze kwestia, którą mogą rozstrzygnąć lekarze: czy taki zabieg, jak kastracja w młodzieńczym wieku, może wpływać znacząco na sprawność intelektualną i aktywność twórczą. Szumowski pisze, że inteligencja u kastrata pozostaje nienaruszona, zmniejsza się natomiast przedsiębiorczość, ruchliwość, rozwija się ociężałość i egoizm ${ }^{125}$. W myśl tej diagnozy, ewentualna kastracja Orygenesa nie musiałaby więc stanąć na przeszkodzie rozwojowi jego geniuszu intelektualnego, trudno jednak pogodzić jakąkolwiek ociężałość, wynikającą z takiego zabiegu, ze znaną ze źródeł sylwetką Orygenesa - człowieka tryskającego energią, niezmiernie ruchliwego, aktywnego, podróżującego, twórcy dwóch instytucji szkolnych, niestrudzonego kaznodziei.

\section{WNIOSKI PODSUMOWUJĄCE}

Mimo opinii większości badaczy o pewności autokastracji Orygenesa, zachowany, dość skąpy, material źródlowy oraz obecny stan badań pozostawiają, moim zdaniem, otwartą kwestię pewności autokastracji Orygenesa. Niespójna wzmianka u Euzebiusza i nie do końca jasna wypowiedź Aleksandryjczyka w Komentarzu do Ewangelii św. Mateusza o młodzieńczej niedojrzałości w interpretacji tekstu Mt 19,12, nie mogą stanowić niezbitych i ostatecznych dowodów, nawet jeżeli inne źródła wspominają o przypadkach takich praktyk, podejmowanych $w$ pierwszych wiekach chrześcijaństwa $z$ pobudek ascetycznych lub pod wpływem niechrześcijańskich kultów i poglądów filozoficznych. Jeżeli uznalibyśmy jednak wspomniany materiał dowodowy za wystarczający i przyjęlibyśmy autokastrację Aleksandryjczyka za fakt, należy pamiętać, że przednicejski kontekst historyczny wpływa łagodząco na jego czyn ${ }^{126}$. W świetle

125 Szumowski, dz. cyt., s. 36.

126 Brak zdecydowanego potępienia autokastracji w pierwszej reakcji biskupa Demetriosa, opisanej przez Euzebiusza, a także brak do soboru nicejskiego ogólnokościelnego prawa zabraniającego kastracji i udzielania święceń kapłańskich kastratom każą inaczej oceniać rzekomy czyn Aleksandryjczyka, niż gdyby miał on miejsce w późniejszym okresie dziejów wczesnego Kościoła, po orzeczeniu Soboru Nicejskiego. 
krytyki dosłownej interpretacji tekstu Mt 19,12, jaką zawarł Orygenes w swoim Komentarzu, należy również patrzeć na jego ewentualną autokastrację jako na swoisty „wypadek przy pracy”, spowodowany młodzieńczą gorliwością i nieprzemyślaną decyzją, a także jako na swoistą „błogosławioną winę”, gdyż dojrzały Aleksandryjczyk, rozpoznawszy swój błąd, stał się orędownikiem i ojcem duchowego eunuchizmu. Trzeba też pamiętać, że kastracja Orygenesa, jeśli w ogóle miala miejsce, nie musiala dokonać się przy pomocy noża i nie była całkowita, tak przynajmniej pozwalają domniemywać teksty Euzebiusza i Epifaniusza.

Przeciw autentyczności czynu Aleksandryjczyka może świadczyć, oprócz wspomnianej małej liczebności i niejednoznaczności źródeł, funkcjonujące w tradycji aleksandryjskiej już przed Orygenesem zdecydowanie duchowe

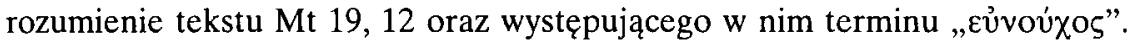
Nie jest wykluczone, że właśnie wieloznaczność tego terminu mogła doprowadzić podczas sporów orygenesowskich do przypisania Aleksandryjczykowi tytułu „eunucha” w znaczeniu „kastrat”, podczas gdy on mógł być tylko „eunuchem duchowym”, czyli człowiekiem, który zdecydował się na bezżenność $\mathrm{z}$ pobudek duchowych. Trudno również pogodzić rzekome dosłowne zrozumienie przez młodego Orygenesa tekstu Mt 19, $12 \mathrm{z}$ jego egzegezą alegoryczną Biblii, praktykowaną przez całe życie z przekonaniem i głęboką pasją oraz ze zdecydowanym odrzuceniem w zachowanych dzielach literalnej interpretacji wspomnianego tekstu Ewangelii.

Nie ma więc jednoznacznej odpowiedzi na pytanie postawione w tytule artykułu i najprawdopodobniej nigdy nie zostanie ona ostatecznie udzielona. Tak jak pionierska myśl Aleksandryjczyka była teologią poszukiwań, hipotez i intuicji, tak też, paradoksalnie, na skutek szczupłości źródel i burzliwych pośmiertnych dziejów Orygenesa, stawiamy prawdopodobne hipotezy co do przebiegu jego życia. Nie kryję swojej sympatii dla twórczości autora Contra Celsum, stąd nieco apologetyczny ton niniejszego artykułu. Wydaje mi się jednak, że jeśli nawet mam takie pragnienie, zeby Orygenes się nie wykastrował, to $\mathrm{z}$ jego własnych pism wynika przeciez, że on sam wolałby tego nie zrobić.

\section{L'AUTOCASTRATION D'ORIGNE - FAIT OU MALENTENDU?}

(Résumé)

L'article présente les arguments pour et contre l'authenticité de l'automutilation d'Origène, en montrant à l'occasion le contexte historique du problème de castration dans l'Église ancienne. Selon l'auteur, les rares sources conservées (des mentions 
isolées chez Eusèbe de Césarée, Jérôme, Épiphane de Salamine ainsi qu'une déclaration plutôt obscure d'Origène lui-même dans son Commentaire sur saint Matthieu sur l'interprétation du texte de $M t 19,12$ ) ne peuvent pas fournir de preuve définitive de l'autocastration d'Alexandrin, même si les autres documents - par exemple l'Apologie de saint Justin, les Actes (gnostiques) de Jean, les Sentences de Sextus, le Panarion d'Épiphane, les Philosophoumena d'Hippolyte, les Canons Apostoliques ou le canon 1 du Concile de Nicée - parlent de cas semblables, pratiqués dans les premiers siècles du christianisme pour des motifs ascétiques ou sous l'influence des cultes païens (surtout d'Atys et de Cybèle).

Si l'on reconnaît cependant l'autocastration d'Origène comme un fait (ce que déclare la majorité des savants), il ne faut pas oublier, que le contexte historique et juridique de la période pré-nicéenne admet des circonstances atténuantes pour un acte de ce genre. De plus, dans son Commentaire sur saint Matthieu, Origène critique avec ardeur l'interprétation littérale du texte de $M t 19,12$. Il faut donc voir son éventuelle castration comme un résultat d'une décision provoquée par un zèle juvénile irrationnel.

Certains savants doutent de l'authenticité de l'acte (K.F. Schnitzer, F. Böhringer, A. Harnack, E. Klostermann, H. Chadwick, I. Dechow). Selon l'auteur de l'article, l'interprétation spirituelle du texte de $M t 19,12$ (surtout du terme ,eunouchos"), bien connue dans la tradition alexandrine avant Origène (chez Clément d'Alexandrie), peut témoigner contre l'autocastration de l'Alexandrin. Ce sont justement les significations différentes de ce mot qui pouvaient faire qualifier Origène de castrat, alors qu'il était simplement „eunouchos” spirituel, c'est-à-dire décidé à rester célibataire, vivant dans la chasteté. On peut donc expliquer sa prétendue castration comme un malentendu terminologique. En tout cas, il est presque impossible de concilier un acte de castration avec l'exégèse allégorique pratiquée par Origène pendant toute sa vie. Même si Origène s'est mutilé, ses propres oeuvres témoignent qu'il aurait préféré ne pas le faire et elles servent à toute l'époque patristique d'exhortation à l',,eunuchisme spirituel". 